\title{
Climate Effects and Stature since 1800
}

\section{Gregori Galofré-Vilà, Aravinda Meera Guntupalli, Bernard Harris and Andrew Hinde}

\begin{abstract}
During the last 30 years, economic and social historians have collected and analyzed large amounts of anthropometric data to explore key aspects of the human past. Attention has also been devoted to the examination of factors that can exert an influence on stature. This article outlines the different ways in which climate might influence stature, either directly or indirectly. It then uses geographical information system software to explore the relationship between variations in temperature and precipitation and the average heights of men in France, India, Mexico, Spain, and the United States over the last two centuries. It is possible to observe an influence of climate on stature in some countries, especially during the nineteenth century, but the relationship weakens across time and largely disappears in recent decades. The attenuation of this relationship is attributed to a process of "technophysio evolution" as countries modernized and developed economically.
\end{abstract}

\section{Introduction}

The world's climate is of interest to historians and economists because environmental conditions affect the health and development of the entire population. According to the Intergovernmental Panel on Climate Change (IPCC), "Weather and climate have a profound influence on life on Earth. They are part of the daily experience of human beings and are essential for health, food production and wellbeing" (IPCC 2001: 87). ${ }^{1}$ However, it has often proved difficult to establish a clear connection between climate and measures of health and well-being. One reason for this has been a shortage of adequate meteorological data. Another is that climate is related to health through multiple complex pathways. A third is the difficulty of choosing a suitable measure of well-being that can be applied to different countries over long periods.

One solution to the third challenge is that adopted by anthropometric historians who use height and weight to investigate the health and well-being of earlier generations (Floud et al. 2011). Height is a cumulative measure of conditions affecting the life of the individual throughout the growth period and is affected by the quality and quantity of an individual's diet and the demands placed on the body's resources by exposure to disease and the use of energy for play and work. Genes are very

1. Climate refers to the average weather pattern in a place over a relatively long period and weather to the mix of events that happen in the atmosphere during a short period. In this article we are concerned with long-run changes in climate, and not on the impact of short-run events (such as storms or heat waves). 
important at the individual level; however, nutritional and environmental conditions from conception to maturity determine how far genetic potential is realized during development. During the last two decades, anthropometric historians have become increasingly interested in the relationship between height and a wide range of social, economic, and environmental factors such as disease, inequality, urbanization, and food prices, but the extent to which meteorological factors may have influenced height has not been examined in as much detail.

One of the main challenges associated with the use of meteorological data is their inherent seasonality. Because meteorological variables display large short-period volatility, scholars have smoothed the data using moving averages or other filters. Although these techniques help to ensure that long-term fluctuations are highlighted, they can also obscure the impact of seasonal variability, which can be vital for agricultural production. A second problem is the absence of data for specific geographical areas. For example, when Baten (2001) examined the relationship between temperature and height in eighteenth-century Bavaria, he used information on winter temperatures in Switzerland. Similarly, when Komlos et al. (2003: 180-83) undertook their investigation into the determinants of height in seventeenth- and early-eighteenth-century France, they used climatic data from Paris, England, and Switzerland.

These problems increase the further back in time one travels. Steckel and Rose (2002) incorporated height measurements into a health index and then compared variations in the value of this index with a range of factors, including settlement size, topography, and climate. ${ }^{2}$ Due to the absence of more precise data, they categorized climates as being either tropical, subtropical, or temperate. They were somewhat surprised to conclude that the "climatic distinctions were irrelevant for the health index," and they suggested that "this might be the result of insufficient diversity in our sample and/or poor measures of climate" (ibid.: 567-87). ${ }^{3}$

Despite these difficulties, a number of scholars have found evidence of a relationship between climatic variables and stature in different parts of the world over the last three centuries. Baten (2001) concluded that warm winters had a positive effect on the heights of men who grew up in Bavaria during the eighteenth century because farmers were able to increase the production of grains and protein sources. Komlos et al. (2003) argued that increasing temperatures led directly to increases in stature in France because people needed fewer calories to keep warm; in addition, lower levels of summer and autumn rainfall had an indirect effect through increased food production. More recently, Challú (2009) found that in Mexico drought and El Niño Southern Oscillation (ENSO) events had a negative impact on the heights of people growing up between 1730 and 1830 because of reduced access to food; Agüero (2014) reported a similar relationship during the second half of the twentieth century (although Grajales-Porras and López-Alonso [2011] found that the Mexican drought of 1785-86 did not cause a decline in heights).

2. The other components of the index included hypoplasias, anaemia, number of teeth, dental abscesses, infections, and evidence of degenerative joint disease.

3. Galofré-Vilà et al. (2018a) also found it difficult to establish a close relationship between climate and stature over the last 2,000 years in England. 
This illustrates an important point: Even if there is a relationship between climate and stature, one would not necessarily expect it to be consistent within or between countries, or over time. For example, one might expect similar variations in either temperature or rainfall to have a somewhat larger effect in countries with more equable climates than in countries where the normal range of meteorological variations is greater. It is also important to recognize that our ability to moderate the impact of climatic variations on stature has increased dramatically over the last 300 years. Fogel and Costa (1997: 49) argued that through the process of "technophysio evolution"- the synergism between rapid technological change and the improvement in human physiology-increasing human control over the environment has weakened the relationship between natural factors, such as climate, and height.

In this article we "map" changes in the relationship between temperature and precipitation and average male stature over the last 200 years through a multicountry study using modern climatic data reconstructions. We attempt to look at variations in temperature and precipitation within cohorts and discuss how the sensitivity to these variations changed over time with a technique known as rolling regression. Our main aim is to explore the relationship between variations in climate and precipitation and stature, and to examine the extent to which this relationship changed over time. We use an analysis of five countries to illustrate the kinds of responses we can observe.

In the next section, we outline the different ways in which climate might influence stature using a conceptual framework. In sections 3 through 5 (selection of the countries, inference from the samples and climate data) we describe our height data for men born in France, India, Spain, Mexico, and the United States since 1800. In Section 6 (connecting humans and climate) we show how we matched individuals with their climatic correlates through the aid of geographical information systems (GIS) software. In section 7 (climate effects on stature) we examine the extent to which the relationship between stature and climate has changed over time within birth cohorts of each of the five countries. Section 8 concludes.

\section{Conceptual Framework}

In figure 1 we depict the four ways in which climate might influence stature through (A) its direct effect on food availability, (B) its direct effect on the disease environment, (C) its influence on the number of calories needed to maintain physiological functioning under different climatic conditions and through the effect of exposure to sunlight on the synthesis of Vitamin D, and (D) its indirect effect on food availability, the disease environment and work intensity.

The originality of this conceptual framework lies in the way these effects are conceptualized and not in the sole identification of the effects. For instance, Komlos et al. (2003) already recognized that climate could affect stature through food supply, and Dell et al. (2014) surveyed the impact of climate on agricultural output, industrial 


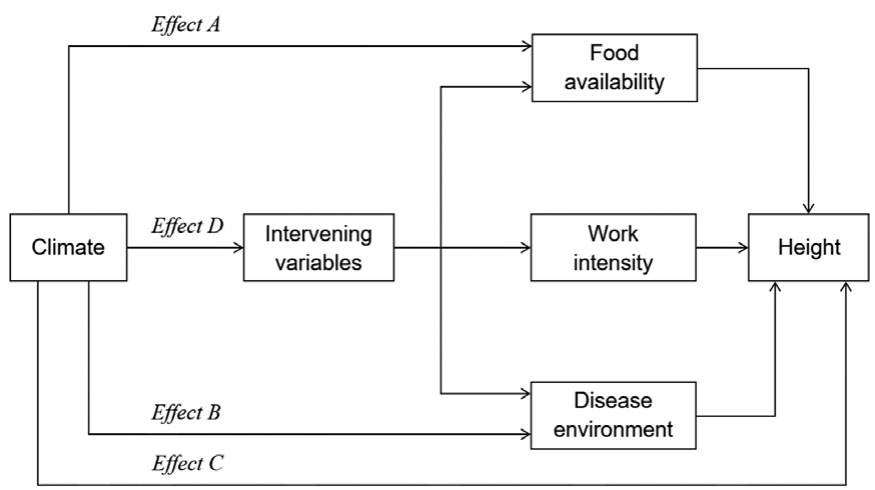

FIGURE 1. Conceptual framework.

output, labor productivity, energy demand, health, conflict, and economic growth. Our aim is to summarize and integrate the relationship between climate and height into one comprehensive picture.

Effect (A) is based on previous anthropometric literature that suggests a relationship between climate and stature through agricultural production (Komlos et al. 2003). Food is the most basic need and changes in food availability can be closely related to changes in height and mortality (Harris et al. 2015). Agriculture is the main source of calories for human consumption, and variations in weather and climate, which can have a direct impact on plant systems and the production of staple foods, could favor arable over pastoral farming or vice versa (Ingram et al. 1981). For instance, climate can affect the choice of crops and level of pastoralism, thereby speeding the pace of land degradation and desertification and limiting the sources of protein intake (Food and Agriculture Organisation 1995). However, technological change such as the kind of agriculture practiced, social customs such as those affecting diet, and the allocation of food within families also appear to be important when considering the relationship between climate and stature through nutrient intake.

Effect (B) reflects the idea that climate can affect stature through its influence over the disease environment. It can affect the spread of vector-borne diseases such as diarrhea, cholera, and malaria (Small et al. 2003). Malaria, which now accounts yearly for more than one million deaths worldwide, weakens the immune system and raises susceptibility to other diseases such as anaemia, and respiratory and rheumatism/musculoskeletal diseases. Martínez-Carrión (1994) found that in Murcia (Spain) between the 1840s and the 1900s the shortest recruits were born in the countryside where malaria was more endemic. Hong (2011) reported that Union Army veterans who spent their childhoods in the most malarial counties of the United States were about $2.8 \mathrm{~cm}$ (1.1 in) shorter at enlistment than those who grew up in the least malarial county. Periods of abundant rainfall can also cause flooding, creating conditions ideal 
for the transmission of water-borne diseases and food-borne infections, inhibiting the proper digestion and absorption of nutrients (Vörösmarty et al. 2000). Some interactions also take place between climate-related diseases and nutrition. Lloyd et al. (2007) estimated that higher rainfall levels increased the incidence of infant diarrhea through contamination of water resources and reduced hygienic practices. Protein absorption is reduced by 10 to 30 percent (and sometimes by as much as 40 percent) in children with diarrhea (Scrimshaw and SanGiovanni 1997). Checkley et al. (2008) calculated that about 25 percent of stunting among infants in developing countries can be attributed to having experienced five or more episodes of diarrhea before the age of two years.

Effect (C) is the direct impact of climate on stature insofar as the body needs to expend higher amounts of energy to maintain its optimal temperature during cold winters and hot summers (Bogin 1999). This is part of the body's thermoregulatory process with heat dissipation in hot environments to avoid hyperthermic stress and heat retention in cold environments to avoid hypothermia. However, the potential magnitude of this effect remains under discussion. Sharpe (2012: 1485) argued that "in cold weather energy is preferentially used to generate heat rather than for growth," but Kelly and Ó Gráda (2013: 1156) claimed that the calorific needs associated with colder temperatures might not be so great and Meredith and Oxley (2014) suggested that they were unknown. It has also been observed that sunlight has a strong effect on the growth rates of children (Bogin 1999). Between 90 to 95 percent of our vitamin D comes from direct sunlight exposure (Holick 2004). For instance, Sharpe (2012) highlighted the effect of insufficient sunlight as a cause of rickets. She argued that nineteenth-century British children were stunted because the effects of urban pollution denied them access to sunlight.

Finally, effect (D) identifies some of the ways in which climate can influence other factors that may affect stature. For example, in very cold or very hot environments, both mental and physical working capacity can be reduced. If this affects earnings, the threat of poverty may be increased. This may also lead to greater demand for child labor, forcing more children into work. Labor market participation could increase children's need for calories, even though it might also increase their entitlement to calories and therefore improve rather than detract from their basic welfare. A change in climate or weather can also damage infrastructure and transport networks, thus hampering trade, which might lead to regional food shortages. If resources are depleted, this can lead to population movements and/or conflicts over the distribution of scarce resources. Climatic conditions may have imposed limits on the scope of urbanisation in the past and encouraged urbanization if they made rural conditions unsustainable. Effect (D) may also confound the relationship between climate and stature insofar as changes in the relationship between height and climate may reflect geographical changes in the distribution of wealth, which are associated with climatic variables. For example, if wealthier people migrate to warmer regions, their children will be taller, but the height of the children might reflect the wealth of the parents more than the warmth of the climate. 


\section{Selection of the Countries}

For the comparative study of the relationship between meteorological conditions and stature encompassing the last 200 years, we have assembled individual male height data for a range of countries based on a collection of data from previously published studies. From the countries with enough data to cover most of the last 200 years, we concentrated on sources that were expected to offer the most consistent samples of the underlying population over time. We avoided data from slave records in Africa or the United States and convict samples from Europe, Latin America, and the United States. Our analysis is confined to males because most of the historical sources only reported the height of adult male populations. We identified studies that appeared to cover a relatively long period (100 to 200 years). We contacted the authors of these papers and some of them agreed to share their data with us. Eventually we were able to gather data from 11 countries. However, in this article we focus only on five: France, India, Mexico, Spain, and the United States. These five countries were selected because they provide good quality data over an extended period and cover a range of different climatic conditions and economic experiences. In two countries (France and Spain) our collection of data for one source was long enough to cover the last 150 to 200 years while, in the other three, we pooled data from different sources. In some cases, we gained access to data for one period (e.g., 1800-75) but not for a subsequent period (e.g., 1875-1950). We also discarded some data because place of birth, a key variable in our study, was not recorded consistently.

Table 1 summarizes key features of the five countries and figure A1 of the online appendix illustrates the main geographical patterns (see online supplementary material). The climate of France has been one of generally cool winters and mild summers with year-round rainfall for the most part, but of mild winters and hot summers in the south. The mean temperature between 1800 and 1999 was $12.4^{\circ} \mathrm{C}$ with a rise of $1.1^{\circ} \mathrm{C}$ over the course of the period. Our height data come mainly from central France and Alsace-Lorraine in the east (though we do have some data from all parts of the country). The average temperatures and rainfall reported in table 1 therefore probably reflect the experience of our sample fairly well. ${ }^{4}$ There was an upward trend in temperature from the 1880s onward, with a rapid warming after the 1970s. Most of France receives a moderate amount of precipitation throughout the year, although regional variations exist within France: $670 \mathrm{~mm}$ in Paris, $800 \mathrm{~mm}$ in Lyon, $980 \mathrm{~mm}$ in Bordeaux, and 1,140 $\mathrm{mm}$ in Brest, with rainfall being greater near the high mountains. The mean annual rainfall since 1800 has been $818.2 \mathrm{~mm}$, with levels decreasing during the second half of the nineteenth century and relatively narrow fluctuations during the twentieth century.

4. The main area from which our data are taken stretches from Paris in the north to the Massif Central in the south, though we also have a substantial amount of data from Alsace-Lorraine. Modern records suggest that these areas have mean annual temperatures and precipitation close to the average for France as a whole. They also include a range of environments, including mountains in the Massif Central. We do, however, have a relative shortage of data from maritime France. 
TABLE 1. Country-level descriptive statistics

\begin{tabular}{|c|c|c|c|c|c|c|c|c|c|c|c|c|c|c|c|}
\hline \multirow[b]{2}{*}{ Period } & \multicolumn{5}{|c|}{ Temperature $\left(\right.$ in $\left.{ }^{\circ} \mathrm{C}\right)$} & \multicolumn{5}{|c|}{ Rainfall (in mm) } & \multicolumn{5}{|c|}{ GDP per head (1990 Int. Geary-Khamis dollars) } \\
\hline & France & India & Mexico & Spain & US & France & India & Mexico & Spain & $U S$ & France & India & Mexico & Spain & US \\
\hline $1800-9$ & 12.6 & $\mathrm{n} / \mathrm{a}$ & $\mathrm{n} / \mathrm{a}$ & 13.5 & $\mathrm{n} / \mathrm{a}$ & 817 & $\mathrm{n} / \mathrm{a}$ & $\mathrm{n} / \mathrm{a}$ & 610 & 1,130 & $\mathrm{n} / \mathrm{a}$ & $\mathrm{n} / \mathrm{a}$ & $\mathrm{n} / \mathrm{a}$ & $\mathrm{n} / \mathrm{a}$ & 1,333 \\
\hline $1810-19$ & 12.2 & $\mathrm{n} / \mathrm{a}$ & $\mathrm{n} / \mathrm{a}$ & 12.5 & 7.7 & 789 & 1,157 & $\mathrm{n} / \mathrm{a}$ & 599 & 1,133 & $\mathrm{n} / \mathrm{a}$ & $\mathrm{n} / \mathrm{a}$ & $\mathrm{n} / \mathrm{a}$ & $\mathrm{n} / \mathrm{a}$ & 1,394 \\
\hline $1820-29$ & 12.7 & 23.5 & $\mathrm{n} / \mathrm{a}$ & 13.5 & 8.4 & 791 & 1,171 & $\mathrm{n} / \mathrm{a}$ & 592 & 1,030 & 1,202 & $\mathrm{n} / \mathrm{a}$ & $\mathrm{n} / \mathrm{a}$ & $\mathrm{n} / \mathrm{a}$ & 1,440 \\
\hline $1830-39$ & 12.5 & 23.3 & $\mathrm{n} / \mathrm{a}$ & 13.4 & 8.2 & 811 & 1,074 & $\mathrm{n} / \mathrm{a}$ & 611 & 1,036 & 1,298 & $\mathrm{n} / \mathrm{a}$ & $\mathrm{n} / \mathrm{a}$ & $\mathrm{n} / \mathrm{a}$ & 1,702 \\
\hline $1840-49$ & 12.4 & 23.3 & $\mathrm{n} / \mathrm{a}$ & 13.4 & 8.2 & 875 & 1,088 & $\mathrm{n} / \mathrm{a}$ & 645 & 1,002 & 1,502 & $\mathrm{n} / \mathrm{a}$ & $\mathrm{n} / \mathrm{a}$ & $\mathrm{n} / \mathrm{a}$ & 1,756 \\
\hline $1850-59$ & 12.4 & 23.5 & 20.2 & 13.4 & 8.3 & 828 & 1,113 & $\mathrm{n} / \mathrm{a}$ & 635 & 901 & 1,681 & $\mathrm{n} / \mathrm{a}$ & $\mathrm{n} / \mathrm{a}$ & 1,144 & 2,082 \\
\hline $1860-69$ & 12.7 & $\mathrm{n} / \mathrm{a}$ & 20.5 & 13.6 & 8.4 & 810 & 1,105 & $\mathrm{n} / \mathrm{a}$ & 614 & 910 & 1,920 & $\mathrm{n} / \mathrm{a}$ & $\mathrm{n} / \mathrm{a}$ & 1,242 & 2,368 \\
\hline $1870-79$ & 12.6 & 23.7 & 20.4 & 13.5 & 8.4 & 817 & 1,159 & $\mathrm{n} / \mathrm{a}$ & 614 & 971 & 2,035 & $\mathrm{n} / \mathrm{a}$ & $\mathrm{n} / \mathrm{a}$ & 1,486 & 2,594 \\
\hline $1880-89$ & 12.3 & 23.6 & 20.2 & 13.1 & 8.3 & 805 & 1,182 & $\mathrm{n} / \mathrm{a}$ & 625 & 937 & 2,243 & $\mathrm{n} / \mathrm{a}$ & $\mathrm{n} / \mathrm{a}$ & 1,659 & 3,302 \\
\hline $1890-99$ & 12.5 & 23.9 & 20.3 & 13.4 & 8.4 & 769 & 1,165 & $\mathrm{n} / \mathrm{a}$ & 603 & 891 & 2,603 & 581 & $\mathrm{n} / \mathrm{a}$ & 1,681 & 3,613 \\
\hline 1900-9 & 12.6 & 23.9 & 20.3 & 13.4 & 8.4 & 762 & 1,040 & 681 & 586 & 727 & 2,927 & 641 & 1,528 & 1,862 & 4,630 \\
\hline 1910-19 & 12.6 & 23.8 & 20.4 & 13.3 & 8.5 & 862 & 1,112 & 692 & 607 & 704 & 3,135 & 685 & 1,751 & 2,028 & 5,222 \\
\hline $1920-29$ & 12.8 & 23.9 & 20.6 & 13.6 & 8.7 & 803 & 1,066 & 707 & 566 & 719 & 3,956 & 693 & 1,861 & 2,408 & 6,174 \\
\hline $1930-39$ & 12.9 & 23.9 & 20.7 & 13.7 & 9.0 & 886 & 1,115 & 734 & 622 & 678 & 4,323 & 694 & 1,659 & 2,283 & 5,749 \\
\hline $1940-49$ & 13.1 & 24.0 & 20.9 & 13.9 & 8.9 & 751 & 1,133 & 698 & 596 & 741 & 3,552 & 658 & 2,116 & 2,151 & 9,661 \\
\hline $1950-59$ & 13.0 & 24.2 & 20.9 & 13.9 & 8.9 & 806 & 1,118 & 730 & 607 & 703 & 6,105 & 669 & 2,698 & 2,736 & 10,556 \\
\hline $1960-69$ & 12.9 & 24.1 & 20.7 & 13.7 & 8.7 & 857 & 1,059 & 766 & 673 & 710 & 9,013 & 786 & 3,617 & 4,575 & 13,157 \\
\hline $1970-79$ & 12.9 & 24.2 & 20.6 & 13.5 & 8.8 & 835 & 1,154 & 751 & 623 & 761 & 13,067 & 884 & 5,041 & 7,972 & 16,745 \\
\hline $1980-89$ & 13.2 & 24.3 & 20.8 & 14.1 & 9.1 & 840 & 1,133 & 795 & 568 & 750 & 15,698 & 1,079 & 6,132 & 9,960 & 20,410 \\
\hline $1990-99$ & 13.7 & 24.4 & 21.1 & 14.5 & 9.3 & 850 & 1,165 & 773 & 550 & 792 & 18,323 & 1,527 & 6,389 & 13,163 & 24,801 \\
\hline
\end{tabular}

Sources: For the climatic data see text in section 5 (Climate Data). GDP per capita from the Maddison Project Database (www.ggdc.net/maddison/maddison-project/home.htm [accessed April 11, 2017]) 
Spain's climate is characterized by cold winters, hot summers, and low and irregular rainfall. Our height data are concentrated in the Spanish Mediterranean Levant (Murcia and Valencia), which is characterized by very mild winters and long warm to hot summers, though we have some data from most areas of Spain apart from the northern and northwestern littoral (see figure A1 in the online appendix). Average temperature and rainfall from 1800 to 1999 were $17.2^{\circ} \mathrm{C}$ and $364.8 \mathrm{~mm}$ in the Mediterranean area $\left(13.5^{\circ} \mathrm{C}\right.$ and $607.3 \mathrm{~mm}$ in Spain as a whole). Similar to France, over the period 1800-1999 mean temperatures in Spain rose by about $1^{\circ} \mathrm{C}$, despite falls during the 1810s, 1880s, and 1970s. Low levels of rainfall were observed in the 1900s, 1920s, and after 1980 with a more significant downward trend when compared to France.

Mexico's climate varies from semi-arid in the north to subhumid in the south. Our height data for the nineteenth and early twentieth centuries come mainly from military records for the Bajío region, supplemented by a smaller proportion of passport holders from urban areas. For the second half of the twentieth century we use a nationally representative survey. The Bajío region lies toward the middle of this climatic gradient with a moderately arid climate. We believe, therefore, that the national-level climate series probably reflect the experiences of this region reasonably well. We do not have data for the first half of the nineteenth century, but the mean temperature in Mexico since the $1850 \mathrm{~s}$ was $20.6^{\circ} \mathrm{C}$ with a rise of $0.9^{\circ} \mathrm{C}$ by the year 2000 . Mean rainfall since 1901 was $732.7 \mathrm{~mm}$, and also shows an upward trend with decades of abundant rain such as the 1930s and 1960s. However, rainfall is particularly low in the northwest coastal zone and regions such as Tijuana receive less than $250 \mathrm{~mm}$ per year.

Even though the bulk of India has a tropical climate, its climate is influenced by the Himalayas and the Thar Desert, and the wide variety of terrain leads to a wide variety of climatic conditions. Agriculture and life in most of India is highly dependent on the kharif (the country's monsoon wet-season crop), cultivated from June to September during which period around 90 percent of India's rain falls. The country can be divided roughly into seven climatic regions: the northern mountains with the Himalayas and their foothills; the northern plains, a low-lying region from Punjab to the Ganges delta with a humid subtropical climate; the Rajasthan Desert, being one of the warmest places in India with low rainfall; the Deccan plateau in central India, ranging from a semi-arid climate in the north to tropical in the rest of the region; the west coast, where rainfall is abundant during the monsoon season and heat can be very oppressive because of the humidity; the southeast coastlands, which are also exposed to monsoon rains with a rise in temperature and humidity; and Assam in the extreme northeast, being a region of mountains with a similar climate to that of the northern plains. While the data collected from the twentieth century cover large parts of northern, western, and eastern India, our nineteenth-century data are mostly from Uttar Pradesh and surrounding states in the northern plains, but we also have some data from southern states, as the geographical composition of the sample changed over time (Brennan et al. 1997). ${ }^{5}$ The average temperature in India between

5. The data derive from the ports of Kolkata (Calcutta) and Chennai (then known as Madras). Kolkata is in northeastern India and most people using Kolkata came from Uttar Pradesh and Bihar, with some from 
1813 and 1999 was $23.9^{\circ} \mathrm{C}$ (with a rise of $0.9^{\circ} \mathrm{C}$ across that period) while temperatures in Uttar Pradesh also showed an upward trend increasing from $24^{\circ} \mathrm{C}$ in 1850 to $25.5^{\circ}$ $\mathrm{C}$ in 2010. With an average rainfall level of $1,121.5 \mathrm{~mm}$ each year, the levels of rain rose during the second half of the nineteenth century, fell at the start of the twentieth century and then fluctuated more widely until the 1970s. However, decadal trends might hide some important seasonal fluctuations such as in Uttar Pradesh, where rain is primarily a summer phenomenon through the southwest monsoon.

We also collected data for the United States, which has a wide range of topographical, ecological, and environmental conditions. West of the 100th meridian are the Great Plains with a semi-arid climate and east of the 100th meridian the climate changes with latitude from humid subtropical in the south to humid continental in the north. Tropical cyclones and hurricanes are not uncommon on the east coast, with warm or hot summers, cold and snowy winters, and rain in all seasons. Most of our nineteenth-century data are from the north and east regions with a temperate humid climate and hot summers and cold winters with snowfall, though for the twentieth century the data are for the entire country. The mean temperature between the $1810 \mathrm{~s}$ and 1999 was $8.6^{\circ} \mathrm{C}$ (with a rise of $1.6^{\circ} \mathrm{C}$ across that period) starting with an upward trend in temperature until the 1940s, then a leveling off for a decade or two before a new warming in recent decades. Average rainfall fell from around 1,130 mm per year during the $1800 \mathrm{~s}$ and $1810 \mathrm{~s}$ to just over $700 \mathrm{~mm}$ at the start of the twentieth century. It then leveled off before rising from the 1950s onward.

The five countries selected for analysis also showed different levels of economic and social development over the last 200 years. In France, gross domestic product (GDP) per head increased steadily between 1800 and 1910 but then declined during the world wars. The urban population only surpassed the rural in the 1930s (Heyberger 2014) and, as late as $1870,50.6$ percent of the male labor force remained in agriculture (Crafts 1985: 57). According to Heyberger (2014), the population of France before 1850 derived most of its protein from grains: Only after that date did the consumption of meat and milk increase. The country's leading crops are wheat, sugar beet, corn, barley, potatoes, fruit, and grapes for wine.

In Spain, real GDP per head has been among the lowest of the advanced capitalist countries since 1850 . Slow growth was accompanied by delayed structural change, and until around 1900 two-thirds of the active population worked in agriculture. The Mediterranean Levant was a region with relatively high labor productivity that "owed much to a combination of a warm climate, irrigation systems, artificial fertilisers and abundant labour which permitted the production of high value crops" (Simpson 1995). Regarding the structure of crops, in Valencia there were oranges, rice, almonds, and a varied range of horticultural products; and in Murcia, fruits, vegetables, and lemons: In both cases, they were easily exported to European markets (Galofré-Vilà et al. 2018b). In the 1930s the Spanish diet shifted from a monotonous diet based on bread,

Assam and West Bengal. Chennai is in south India and most people using Chennai came from the states of Tamil Nadu, Ketala, Karnataka, and Andhra Pradesh. The largest contingent in our data set came from Uttar Pradesh. 
potatoes, and legumes to a richer system with the consumption of meat, milk, animal fats, fruits, and vegetables, positively affecting heights (Cussó Segura and Garrabou 2007).

Mexico is a middle-income country with a GDP per head currently far below that of European countries, though at the start of the twentieth century it was not far below that of Spain. Mexico's economy is inextricably connected to the larger economy of the United States. Since 1800 Mexico has gone through periods of sluggish economic performance, war, revolution (1910-20), rapid export-led growth during the early phases of independence (1821) and the Porfiriato regime (1876-1911), and government-managed industrial modernization (1920-50), with sustained growth that started around 1940 and lasted until 1980. The share of the active population in agriculture was 62 percent in 1900, 70 percent in 1929, and 66 percent in 1950; it only fell to 50 percent in 1970 (Prados de la Escosura 2007). The staple crops were corn, beans, and squash, and López-Alonso (2012: 13) contends that the dietary habits of the majority of the population barely changed between 1850 and 1950. The central northern part of the country and the Bajío region, from which most of our data come, were cattle-raising regions (ibid.: 116), which might explain why individuals from these regions were somewhat taller than their southern counterparts from more urbanized and industrial places.

India's GDP per head is the lowest of the countries under investigation: It showed stagnation until the second half of the twentieth century and increased rapidly thereafter. However, the GDP per head achieved in 2000 was similar to the level of Spain in 1950, France in 1900, and the United States in 1850. India's economy, despite industrial development in Bombay and Calcutta during the colonial period (1857-1947), has always been tied to the agricultural sector, which has occupied about two-thirds of its working population with little change over time (Roy 2005). Indian agriculture was characterized by some of the lowest yields on record and tropical climate and attendant water scarcity limited the prospect of agricultural commercialization to only a few regions. India's main crops such as cassava, rice, millet, wheat, and pulses varied across regions. In Uttar Pradesh, for example, average annual rainfall varies from 25 to 50 in (64 to $128 \mathrm{~cm}$ ) and crops include wheat, millet, pulses, sugar cane, and rice (on irrigated land in the drier areas) (Brennan et al. 1994: 276).

The United States had the highest GDP per head of the five countries throughout the period under review. GDP increased steadily between 1800 and 1929, with a fall during the depression of 1929 and World War II and a rapid increase thereafter. In 1800 , the United States was a largely agricultural economy, with approximately threequarters of the labor force occupied in that sector. Later, industry and services gained prominence at the expense of agriculture. On the eve of the Civil War (1861-65), agriculture's share of the labor force was 55.8 percent; it fell to 30.7 percent in the 1910s, 12.0 percent in the 1950s, and 2.4 percent in the 2000s (Carter et al. 2006: 218). Olmstead and Rhode (2008: 4-18) argue that, although agricultural development depended on changing technological and market forces, bad weather could affect farm output, and probably affected it more than price changes. They also show that over the last 200 years, corn has been the predominant crop in terms of acreage: Between 
1910 and 1925, three-tenths of national cropland harvested was devoted to raising this one crop. The main crops in the US South are cotton, oats, barley, and sugar, and (in the Pacific region) fruit and vegetables. The Central region specializes in field crops such as corn, soybeans, and wheat, and northeastern states produce oats and barley, rye, hay, and wheat. Livestock is mostly found in the central and northeastern regions, in the southern plains and in the southeast.

\section{Inference from the Samples}

To collect sufficient data for the five countries under review since 1800, we used height data from a variety of sources, including migrants, military recruits, and medical surveys (table 2). For France and Spain, we first use conscript data. We then in France use data from the Eurobarometer surveys conducted by the European Commission to monitor public health and opinion in the European member states, and the International Social Survey Programme, a cross-national collaboration to monitor public health in its member countries.

Our data for nineteenth-century India are derived from indentured workers who migrated from the present states of Tamil Nadu, Andhra Pradesh, Bihar, and Uttar Pradesh to Fiji, Jamaica, Mauritius, and Natal to work on sugar cane plantations. Brennan et al. (1997: 194) explained that, although these men came from the lower socioeconomic groups, the fact that they "had to pass a stringent medical examination attesting to their good health and physical ability to perform the arduous manual labour required in sugarcane farming" meant that "they were not the weakest and sickliest members of the lower strata." In some years, the selection criteria focused on chest circumference but "recruiting authorities used ... height only for purposes of identification and ... short recruits were not generally rejected" (Brennan et al. 1994: 277). For the first half of the twentieth century we use nationally representative data from the All India Anthropometric survey carried out in the 1960s (Guntupalli and Baten 2006) covering large parts of North, West and East India. For the second half of the twentieth century we use data from the India Human Development Survey (Desai et al. 2005), which is a nationally representative survey carried out in 2004-5.

For Mexico and the United States we use migrant, military, and survey data. Mexican military recruits mostly came from Bajío and other central-north states such as Durango, Zacatecas, Nuevo León, and Coahuila, with very few from the extreme arid north (Baja California and Sonora) or from tropical southern states (such as Guerrero or Chiapas). They had to meet some basic requirements such as Mexican citizenship, the ability to use weapons, absence of physical and intellectual deficiencies, and a height of at least $160 \mathrm{~cm}$ (López-Alonso 2012). We also use men who requested passports for travel abroad, and who were more representative of the middle and upper classes of Mexican society. To cover the second half of the twentieth century we use data from the ENSANUT (Encuesta Nacional de Salud y Nutrición), a nationally representative health and nutrition survey carried out in Mexico in 2012. 
TABLE 2. Sources and descriptive statistics of height data

\begin{tabular}{|c|c|c|c|c|c|c|c|c|c|c|c|}
\hline \multirow[b]{2}{*}{$\begin{array}{l}\text { Place } \\
\text { of birth }\end{array}$} & \multirow[b]{2}{*}{$\begin{array}{l}\text { Period of } \\
\quad \text { birth }\end{array}$} & \multirow[b]{2}{*}{ Source } & \multirow[b]{2}{*}{$\begin{array}{c}\text { Initial } \\
\text { observations }\end{array}$} & \multicolumn{7}{|c|}{ Rejected observations } & \multirow[b]{2}{*}{$\begin{array}{l}\text { Retained } \\
\text { observations }\end{array}$} \\
\hline & & & & $\begin{array}{l}\text { Incomplete } \\
\text { or missing } \\
\text { information } \\
\text { about place } \\
\text { of birth }\end{array}$ & $\begin{array}{l}\text { Foreign } \\
\text { birth } \\
\text { country }\end{array}$ & $\begin{array}{l}\text { Incomplete } \\
\text { information } \\
\text { about age } \\
\text { and/or year } \\
\text { of birth }\end{array}$ & $\begin{array}{l}\text { Individual } \\
\text { measured } \\
\text { below } \\
\text { mature } \\
\text { height }\end{array}$ & $\begin{array}{l}\text { Individual } \\
\text { aged older } \\
\text { than } 50 \\
\text { years }\end{array}$ & $\begin{array}{l}\text { Implausible } \\
\text { measurement }\end{array}$ & $\begin{array}{c}\text { Total } \\
\text { rejected } \\
\text { observations }\end{array}$ & \\
\hline France & $1782-1920$ & Heyberger (2007) & 207,015 & 173 & 1,554 & 1 & 9,493 & $\mathrm{n} / \mathrm{a}$ & 242 & 11,463 & 195,552 \\
\hline France & $1947-86$ & Eurobarometer $(1996,2003,2010)^{*}$ & 1,506 & 18 & $\mathrm{n} / \mathrm{a}$ & 34 & 52 & 553 & $\mathrm{n} / \mathrm{a}$ & 657 & 849 \\
\hline France & $1962-93$ & $\operatorname{ISSP}(2013)^{*}$ & 1,382 & $\mathrm{n} / \mathrm{a}$ & 30 & 44 & $\mathrm{n} / \mathrm{a}$ & 806 & $\mathrm{n} / \mathrm{a}$ & 880 & 502 \\
\hline India & $1810-96$ & Brennan et al. (1994) & 55,206 & 895 & 276 & 182 & 13,850 & 53 & $\mathrm{n} / \mathrm{a}$ & 15,256 & 39,950 \\
\hline India & $1914-44$ & Guntupalli and Baten (2006) & 26,186 & 217 & $\mathrm{n} / \mathrm{a}$ & $\mathrm{n} / \mathrm{a}$ & $\mathrm{n} / \mathrm{a}$ & $\mathrm{n} / \mathrm{a}$ & $\mathrm{n} / \mathrm{a}$ & 217 & 25,969 \\
\hline India & $1956-84$ & Desai et al. (2005) & 74,369 & 2,384 & $\mathrm{n} / \mathrm{a}$ & 4,985 & 14,919 & 4,205 & $\mathrm{n} / \mathrm{a}$ & 26,493 & 47,876 \\
\hline Mexico & $1842-1958$ & López-Alonso (2003) (military) & 7,088 & $\mathrm{n} / \mathrm{a}$ & $\mathrm{n} / \mathrm{a}$ & $\mathrm{n} / \mathrm{a}$ & 423 & 53 & $\mathrm{n} / \mathrm{a}$ & 476 & 6,612 \\
\hline Mexico & $1876-1915$ & López-Alonso (2003) (migrant) & 2,437 & $\mathrm{n} / \mathrm{a}$ & $\mathrm{n} / \mathrm{a}$ & $\mathrm{n} / \mathrm{a}$ & 67 & 225 & $\mathrm{n} / \mathrm{a}$ & 292 & 2,145 \\
\hline Mexico & $1867-1993$ & ENSANUT (2012) & 40,234 & $\mathrm{n} / \mathrm{a}$ & $\mathrm{n} / \mathrm{a}$ & 3,504 & 20,029 & 5,796 & $\mathrm{n} / \mathrm{a}$ & 29,329 & 10,905 \\
\hline Spain & $1850-1967$ & Martínez-Carrión (2002) & 161,279 & 4,475 & 366 & 23,049 & 13,739 & $\mathrm{n} / \mathrm{a}$ & 491 & 42,120 & 119,159 \\
\hline Spain & $1859-1948$ & Puche (2011) & 157,453 & 34,166 & 243 & 34,652 & $\mathrm{n} / \mathrm{a}$ & $\mathrm{n} / \mathrm{a}$ & $\mathrm{n} / \mathrm{a}$ & 69,061 & 88,392 \\
\hline US & $1815-45$ & Costa (2002) & 20,463 & 6,344 & 2,128 & 560 & 1,871 & 94 & $\mathrm{n} / \mathrm{a}$ & 10,997 & 9,466 \\
\hline US & $1812-45$ & Fogel et al. (1990) & 39,620 & 842 & 10,122 & 1,399 & 7,778 & $\mathrm{n} / \mathrm{a}$ & $\mathrm{n} / \mathrm{a}$ & 20,141 & 19,479 \\
\hline US & $1815-46$ & Steckel (1992) & 6,762 & 29 & $\mathrm{n} / \mathrm{a}$ & 21 & 210 & 1,620 & $\mathrm{n} / \mathrm{a}$ & 1,880 & 4,882 \\
\hline US & $1790-1899$ & Sunder (2013) & 21,700 & $\mathrm{n} / \mathrm{a}$ & $\mathrm{n} / \mathrm{a}$ & $\mathrm{n} / \mathrm{a}$ & 3,975 & 157 & $\mathrm{n} / \mathrm{a}$ & 4,132 & 17,568 \\
\hline US & $1921-58$ & NHANES (1971-75; 1976-80) & 20,135 & $\mathrm{n} / \mathrm{a}$ & 1,462 & 392 & 6,221 & 6,414 & $\mathrm{n} / \mathrm{a}$ & 14,489 & 5,646 \\
\hline US & $1898-1923$ & $\begin{array}{l}\text { World War II Army Enlistment } \\
\text { Records (2005) }\end{array}$ & 27,618 & 4,097 & 506 & 5,691 & 3,351 & $\mathrm{n} / \mathrm{a}$ & 4,318 & 17,963 & 9,655 \\
\hline US & $1886-1957$ & Wu (1994) & 9,362 & $\mathrm{n} / \mathrm{a}$ & $\mathrm{n} / \mathrm{a}$ & $\mathrm{n} / \mathrm{a}$ & 269 & 937 & $\mathrm{n} / \mathrm{a}$ & 1,206 & 8,156 \\
\hline Total & & & 879,815 & 53,640 & 16,687 & 74,514 & 96,247 & 20,913 & 5,051 & 267,052 & 612,763 \\
\hline
\end{tabular}

* Only data for France has been considered.

Notes: The "period of birth" column only includes the retained observations. NHANES: National Health and Nutrition Examination Survey. 
For the United States, our earliest data are drawn from the records of men who served in the Union and Confederate Armies during the American Civil War. Fogel (1993) showed that the land force that fought for the Union during the American Civil War was representative of the whole of the northern population of military age, using wealth and literacy rates. ${ }^{6}$ Using genealogies, he further showed that they experienced the same mortality rates at older ages as the population from which they were drawn. We also used US passport-holding men that represented mostly upper classes, although Sunder (2013: 256) argued that "West Point cadets from 'middle class' family backgrounds exhibit a height trend very similar to the one for passport men." Additionally, we examined a random sample from more than nine million observations from those who enlisted in the army during World War II. To serve in the army a man needed to be able to read and write in English, be between five and six and a half feet $(152.4$ and $198.1 \mathrm{~cm})$ tall, and weigh at least 105 pounds (or $47.6 \mathrm{~kg}$ ) (Bleakley et al. 2013). To get a suitable sample for analysis comparable across time and between samples we selected 0.03 percent of the nine million World War II enlistees at random. We also use data from the National Health and Nutrition Examination Surveys, a program of the National Center for Health Statistics to assess the health and nutritional status in the United States. Finally, we use a random sample of the two million voter registration cards in Pennsylvania (Wu 1994).

The use of height data from previously published studies allows us to examine large amounts of data that have not previously been analyzed together or in the context of studying the effects of climate on stature. Table 2 provides a summary of the data collected with the final retained observations, showing the reasons for discarding data in the "rejected observations" columns. These reasons were that the place of birth was not properly recorded, men had been born outside the present geographical boundaries of the countries under investigation, age at the time of measurement was unknown or date of birth was not properly recorded, a man had not yet attained his mature height, and the height reported in the transcribed data set was manifestly incorrect (e.g., 1,630 cm). After eliminating observations in these categories, we had 612,763 separate observations that could be subjected to further analysis.

Military organizations in nonconscript armies and during peacetime usually applied minimum height requirements, which meant that they excluded the shortest members of the populations from which they were drawn (Fogel et al. 1983). If a particular climatic variable is associated with shorter heights, and if shorter individuals are excluded from the data set, we will have less variation in heights and some part of the height distribution will not be analyzed, which is likely to obscure the true relationship between climate and stature. We used the cumulative distribution function of heights to detect possible points of truncation and then explored how far the samples deviated from a normal distribution with the Normal Quantile Plot and the kernel density distributions for different periods (unreported here). We found that in the nineteenthcentury French and Mexican military samples there was evidence of truncation due to sample. 
minimum height requirements and therefore for these two samples we used truncated regressions to account for truncation in the height distribution (Wachter and Trussell 1982). We used truncated regression to estimate the covariate effects of climate on heights within truncated samples assuming a truncated normal distribution to estimate the standard errors. For Mexico we used the truncated point of $160 \mathrm{~cm}$ and in France the truncated points by place and year of measurement described in Heyberger (2007). For the Mexican case, the sampling of military recruits and passport holders (who were taller than the soldiers) might cause, at most, small compositional effects, as the proportions of both groups are roughly maintained, and both show the same overall height development.

Sometimes it was not possible to determine the year of birth, because information about the year of birth, age, and year of collection was missing or improperly recorded. We also checked for heaping on age with age histograms and the Whipple and Myers' Blended Indices and only found evidence of age heaping in the Indian data sets. Age heaping is a phenomenon more common in poorly educated societies (which are also likely to be short) and "heaping is repeatedly observed in all censuses and [modern] surveys in some countries, and cannot be eliminated even with special training of interviewers" (Pullum 2006: 2). Yet Brennan et al. (1997: 190) claimed that the age data for the nineteenth-century Indian migrant sample were reliable. Nevertheless, in India the greater imprecision in the reporting of age may increase the risk of individuals being allocated to the wrong birth years and hence obscure the relationship between height and climatic conditions at the time of birth. ${ }^{7}$

We link climatic data to the year in which an individual was born because it has often been claimed that this is the period in which growth is most sensitive to environmental and nutritional shocks (Tanner 1962). Moreover, focusing on the first year of life allows us to identify members of the same cohort, while acknowledging the fact that final or mature height reflects the cumulative impact of environmental and nutritional conditions throughout the period of growth. The pattern of human growth in modern well-nourished populations that have grown in a conducive environment shows that a man might attain his mature height at the age of 18-19 years. However, it is possible that growth may be delayed until the age of 20-23 years, or even later in some instances, if environmental or nutritional conditions are less conducive (ibid.). Therefore, only to consider males that stand at mature height, we first estimated the age at which maximum height was attained. We carried out an exploratory analysis of the confidence interval graphs for age groups, proceeding with an analysis of variance test and a post-hoc Bonferroni test at the 90 percent confidence level to identify the yearly age groups with statistically different mean heights.

Some of our data come from military records in which individuals were measured mostly at the ages of 18-22 years, giving an overrepresentation of young individuals who may not have reached their maximum height. This applies to Spain and

7. To address issues of heaping on height (the accuracy of the recorded height measurements) Fogel et al. (1983) showed that even with large amounts of heaping (in the range of 15-30 percent) the error will only be in the region of $0.254 \mathrm{~cm}$ or $0.1 \mathrm{in}$. 
France, so for these countries we have compared our height trends with those derived for men aged between 30 and 40 years from twentieth-century surveys and heights standardized by age: The trends are similar. ${ }^{8}$ After comparing the series with those standardized at the age of 21 years by Martínez-Carrión and Moreno-Lázaro (2007: 151), we agree with their conclusion that in Spain "changes in recruitment age scarcely affected the trend in physical stature."

The data set also contains older individuals: As human beings are known to start shrinking in their late forties or early fifties, we have excluded individuals who were measured above the age of 49 years. A very few observations showed individuals to be abnormally short but no one in the sample was impossibly short. For instance, a 40-year-old man born in Granville (New York), who enlisted in the Union Army in February 1864 for three years, was $121.9 \mathrm{~cm}$ tall and weighed $50.1 \mathrm{~kg}$. While this could be a recording error, it is also possible that this man was suffering from achondroplastic bone-growth disorder or a similar condition, and we have retained his information because the reported height is within the range of possibility.

Figure 2 reports the resulting estimated heights of our samples. The average heights of successive French cohorts since 1800 have grown slowly but with an acceleration in the rate of improvement: $163.5 \mathrm{~cm}$ in the $1800 \mathrm{~s}$ to $165.2 \mathrm{~cm}$ in the $1850 \mathrm{~s}, 168.2 \mathrm{~cm}$ in the $1900 \mathrm{~s}$, and $179.2 \mathrm{~cm}$ in the $1980 \mathrm{~s}$. There were some temporary reverses: For example, "heights ... decreased in Sélestat, and in Saint-Yrieix and Bellac between the 1810s and 1820s, when France was undergoing a prolonged economic crisis" (Heyberger 2007: 240). In Spain mean stature was $161.1 \mathrm{~cm}$ in the $1850 \mathrm{~s}, 164.3 \mathrm{~cm}$ in the $1900 \mathrm{~s}$, and $168.6 \mathrm{~cm}$ in the $1950 \mathrm{~s}$.

In India, average heights show a cyclical pattern of increase in the early nineteenth century (of about $3.1 \mathrm{~cm}$, on average), followed by a decrease in the middle of the century and a moderate increase between the 1860 s and 1870 s. Since the 1880 s there has been a linear monotonic increase in stature of around $0.3 \mathrm{~cm}$ per decade. In the 1830s Indian heights were very similar to those in France (at $162.8 \mathrm{~cm}$ ) and Indians were taller than Spaniards until the birth cohorts of the 1880s.

In Mexico during the Porfiriato period (1876-1911) heights stagnated at around $165-66 \mathrm{~cm}$, then the average value of the heights declined by almost $2 \mathrm{~cm}$ in the 1920 s to $164.3 \mathrm{~cm}$, the period of decline coinciding with the Revolution (during the 1910s) and Cristero War (1926-29). The nineteenth-century levels were not recovered until the 1940s (at $165.7 \mathrm{~cm}$ ) when a welfare system was developed. Thus, although the Mexicans who were born during the 1870s and 1880s were nearly as tall as contemporaneous Frenchmen, the birth cohorts of the 1980s were more than $11 \mathrm{~cm}$ shorter $(167.3 \mathrm{~cm}$ as opposed to $179 \mathrm{~cm})$.

The average heights of men born in the United States stagnated between the $1800 \mathrm{~s}$ and the 1830s (at $174.0 \mathrm{~cm}$ ) then fell in the 1840s and did not increase consistently until the end of the century. ${ }^{9}$ Floud et al. (2011) argued that there were other environmental factors on the side of claims on food intake that substantially reduced the 

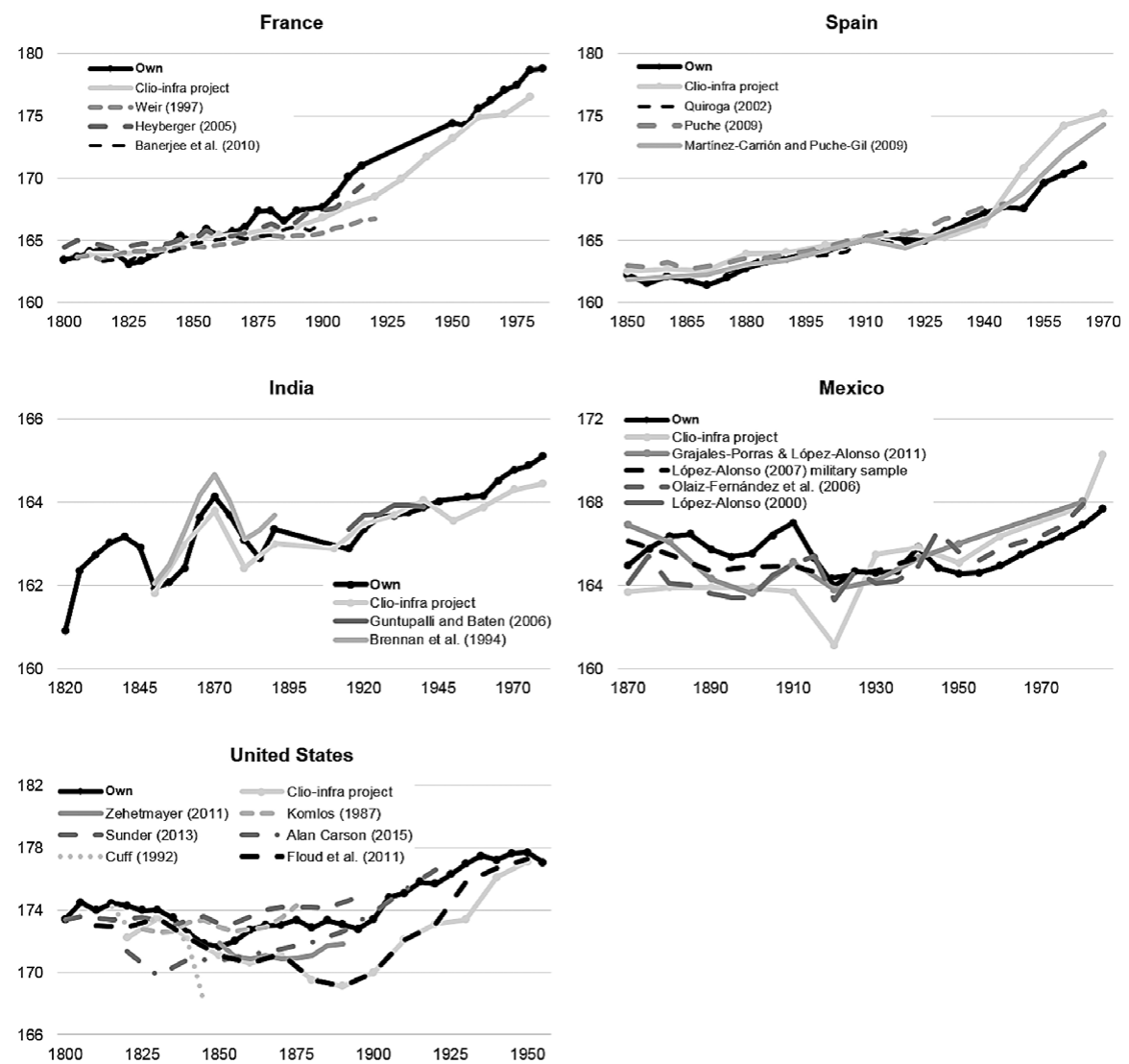

FIGURE 2. Reported height estimates from different sources (in cm).

Sources: See bibliography for details. For Clio-Infra project see www.clio-infra.eu (accessed April 11, 2017).

positive impact of diet on height during this period. During the twentieth century, heights started to increase rapidly (to $178.2 \mathrm{~cm}$ in the 1950s) due to public health interventions, better medical technology, higher incomes, and reduced disparities between rural and urban populations (ibid.). As figure 2 shows, there is disagreement among previous researchers as to the trend in US heights between around 1860 and 1930. The divergence in the series derives from the use of different sources. Figure 2 includes data from Sunder (2013) based on upper-class migrants, Zehetmayer (2011) based on US Army recruits and Carson (2016) based on prison inmates, as well as a series from Floud et al. (2011), which is based on that originally described by Fogel (1986), which used interpolated data from the Ohio National Guard.

Figure 2 also shows the time trend in heights from other comparable studies of each of the five countries. For France, Spain, and India our series are very close to all the 
previous series with which we have compared them. For Mexico the correspondence is very close after 1930, but for the period from about 1880 to about 1910 the men in our sample are rather taller than those in some of the other series. The United States shows the greatest variation between the series produced in previous research. Our series falls close to or within the range spanned by previous series, but between about 1860 and 1920 it lies substantially above that of Floud et al. (2011).

In view of the fact that we have collected our data from previous height studies, our results are, as expected, very similar to those reported from the authors or studies from which we have collected the data. In Mexico and the United States, because we pooled data from multiple sources, it is possible that stature changes over time in our study could deviate from other studies as the composition of our pooled data could differ from studies using part data. Our nineteenth-century Mexican series includes data from migrants and military troops and for the twentieth century we add the data from the ENSANUT (2012) while data from Olaiz-Fernández et al. (2006) are from the previous wave (2006). For the United States we can say that our series relates closely to other measures of well-being, such as the expectation of life at age 10 years reported by Costa (2015) and Fogel (1986) or the crude death rates reported by Floud et al. (2011) (see figure A2 in the online appendix). Additionally, if composition effects were important in the United States, they should be greater in the first half of the nineteenth century, when we pooled data from four different authors/sources. However, in this period the discrepancies are minimal. Unfortunately, we cannot repeat the historical comparison of our height estimates with other health indicators in Mexico, because these additional variables do not exist.

\section{Climate Data}

During recent years meteorologists have used instrument readings to reconstruct climatic data for the twentieth century for the whole world, and back to the 1750 s for the European countries. These data are commonly reported on the basis of grids superimposed on the earth's surface that interpolate station data and other geographic information over a grid of a certain resolution. Most of the data come from ground stations. Dell et al. (2014: 749) argue that "in general, gridded datasets are a good source of temperature data for economic analysis in that they provide a balanced panel that potentially adjusts for issues like missing station data, elevation, and the urban heat island bias in a reasonable way."

Temperature is the degree or intensity of heat present in an element and precipitation is the condensed moisture of the atmosphere falling visibly in separate drops, regulating the circulation of water in the environment. The gridded data are reported as deviations from current values, or anomalies, but we converted them to actual temperatures. A temperature anomaly of $1^{\circ} \mathrm{C}$ at point $i$ in year $t$ means that the temperature at $i$ was $1^{\circ} \mathrm{C}$ higher during $t$ than the mean temperature at $i$ over the period 1950 to 1980 . 
We used the Berkeley Earth Surface Temperature data set that reports the mean monthly daytime temperatures from 1753 to 2000 at $1^{\circ}$ by $1^{\circ}$ grid resolution. ${ }^{10}$ For rainfall, from 1901 until 2000 we use a global monthly data set at $0.5^{\circ}$ by $0.5^{\circ}$ grid resolution from the Climatic Research Unit (CRU) Time-Series (TS) version 3.21 (Harris et al. 2014). We have been able to extend the data set for France and Spain at the same resolution using data for the period 1766 to 1900 from Casty et al. (2007), for India using regional data from the Indian Institute of Tropical Meteorology from 1813 to 1900 , and for the United States using the weather stations reported in Carter et al. (2006) since the 1820s. The information gathered amounted to more than 450 million climatic points since 1750 .

As a robustness check we test for the choice of the climatic data, and we have been able to replicate the results for the twentieth century using the data from CRU TS. Yet, despite our data being among the most widely used data sets, for the nineteenth century, we cannot test our estimates for precipitation as no other climatic data exist for this period.

In discussing the suitability of gridded data sets in statistical analysis, Dell et al. (2014) identified two potential issues: Problems associated with the analysis of "short periods" and problems when there are more grid cells than underlying stations. They suggested that although this second issue "would not necessarily compromise the analysis if the gridded data are aggregated to large enough units (e.g. countries), it can pose challenges for inference regarding smaller geographic units, particularly in areas with sparse coverage, such as Africa." For the first concern, we use yearly instead of monthly data and control for the amount of volatility in our models with the method of the rolling regression. For the second concern, although climatic scientists accounted for missing meteorological stations in less densely population areas when constructing the gridded networks, we grouped individuals across space and time and weighted temperature or precipitation in the country by the number of individuals and their location in a given year (see also next section).

\section{Connecting Humans and Climate}

To assign to individuals the temperatures and precipitation that they were exposed to during their years of birth, we used GIS software to perform a spatial join by location with the Euclidean distance between the place of birth and the climatic grid point. ${ }^{11}$ As an example, figure 3 illustrates how individuals have been geocoded by the place of

\footnotetext{
10. See www.berkeleyearth.org/ (accessed April 11, 2017).

11. Because we have been working with transcribed data sets, rather than original manuscript records, we made some corrections for obvious mistakes in the typing process (e.g., Jolotepec for Yolotepec in Mexico). Further work was needed to ascertain the present names of the locations because some places changed their names over time (Rājputāna for Rājasthān in India). We excluded individuals born in the jurisdictional domain of a country but geographically located far away from the country (such as the Canary Islands in the case of Spain) and, as we used the present borders of the countries, we excluded individuals who were born outside these (e.g., Spanish recruits who were born in Spanish Morocco). Both these cases for removing observations have been recorded under the category of "foreign birth country" in table 2 .
} 


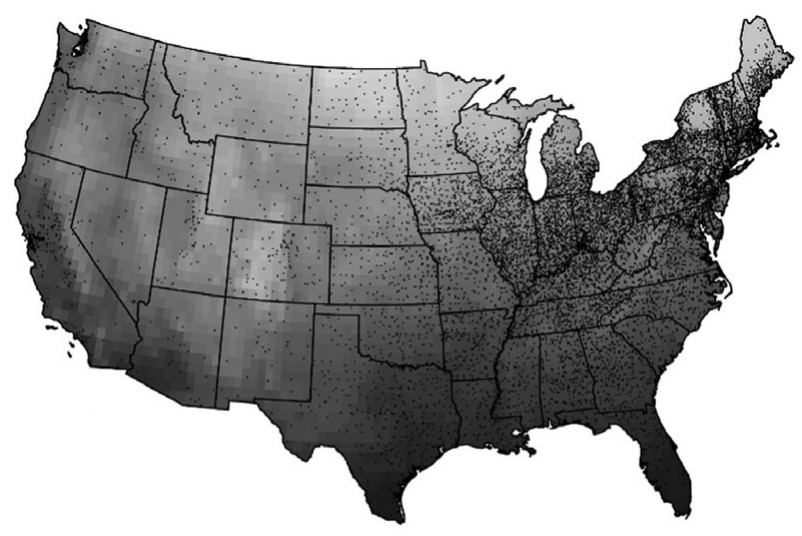

Mean temperatures (1901-2011)

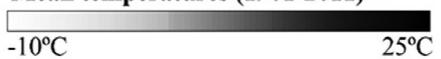

FIGURE 3. Connecting climatic grid cells with individuals in the United States. Sources: For height data see table 2; temperatures from Berkeley Earth Surface Temperature data set (www.berkeleyearth.org [accessed April 11, 2017]).

Note: Place of birth can represent a group of individuals when their place of birth was reported using the same name.

birth in the United States (black dots) and how each individual was assigned climatic information on the basis of the coordinates of each climatic grid cell. Although in most cases place of birth was recorded in a quite detailed fashion (usually to the level of neighborhood, village, town, or county), in some cases we had only the name of the district or state. Precision is necessarily lost in the latter situation, but this does not hinder the analysis greatly as inland meteorological information between contiguous grids does not differ significantly at $0.5^{\circ}$ by $0.5^{\circ}$ or at $1^{\circ}$ by $1^{\circ}$ cell resolution. ${ }^{12}$ Temperature and precipitation are linked to each man in the following way: For man $i$ born in place $k$ in year $t$ we attach the gridded temperature and precipitation in the year $t$ that is closest to place $k$, using GIS software. The assigned temperature and precipitation thus vary in accordance with the place and date of birth of the men in our sample.

We then examine the extent to which the relationship between stature and the two meteorological variables has changed over time within each of the five countries, using a technique known as rolling regression. This method involves calculating the coefficients for the regression of height on either temperature or precipitation in moving windows of a fixed size through the sample and shows whether there is a cross-sectional relationship between a meteorological variable and stature over a

12. We controlled for emigration and excluded observations when the country of birth and measurement were different; these observations are recorded under the category of "foreign birth country" in table 2. 
defined geographical area within a specific period. To see whether the relationship changes over time we repeat the regressions for successive periods in fixed windows where the length of the window allows us to control the volatility of the climatic variables. ${ }^{13}$ To establish the best window for analysis we selected 15-year windows using the middle year as the target year. In comparison to windows of 1, 3, 5, or 11 years, a 15-year window reduces the amount of volatility and shows the same major patterns as shorter windows. In comparison to windows of 21 and 31 years, it involves the discarding of fewer data at the beginning and end of each sequence for which data are available. In turn, this method minimizes the composition effects of pooling data from different samples as the resulting estimates show a sequence of overlapping cross-sectional relationships arranged over time.

We estimate the following equation:

$$
y_{i k t}=\alpha_{\tau k}+\beta_{\tau k}^{T} c_{i k t}+\varepsilon_{i k t}
$$

where $y_{i k t}$ is the dependent variable, stature, for case $i\left(i=1,2, \ldots, N_{k}\right)$, in country $k$ $(k=1,2,3,4,5)$, belonging to year $t(t=\tau, \tau+1, \ldots, \tau+14)$. The equation refers to overlapping intervals labeled $\tau(\tau=1,2, \ldots, P)$. Additionally, $\alpha_{\tau k}$ is the intercept for country $k$ in overlapping interval $\tau, c_{i k t}$ is the climatic variable of interest, $\beta_{\tau k}$ is the coefficient on the climatic variable for the window $\tau$, and $\varepsilon_{i k t}$ is the error term. We computed robust standard errors to take account of the clustering in the data because several individuals can share the same temperature and precipitation grid cells.

\section{Climate Effects on Stature}

Figure 4 presents the estimated regression coefficients with their 95 percent confidence intervals over time for a succession of overlapping 15-year periods when temperature is the climatic variable. In France between 1800 and the early twentieth century there was generally a negative relationship between mean temperature and height (warmer temperature associated with shorter stature), though the association turned positive for a time in the 1850s and 1860s. The data available after the 1950s suggest no significant relationship. In Spain there was a negative association during the $1880 \mathrm{~s}$, but there was also a consistent and increasingly strong positive association from the early 1900s onward. In India there was a positive relationship during the $1830 \mathrm{~s}$ and $1840 \mathrm{~s}$, but this turned to a consistent negative association from the $1850 \mathrm{~s}$, and it was not until the 1950s that a positive relationship emerged. In the United States, we find a positive association between temperature and height between the 1810s and 1850 s, followed by a mainly nonsignificant relationship until the 1930s when a negative relationship appeared. In Mexico the association was generally negative, but it

13. The creation of overlapping periods might create serial correlation. However, annual regressions showed similar results to windows of 15 years and, because we restrict our estimation to the window, within the window the ordinary least squares assumptions hold. 

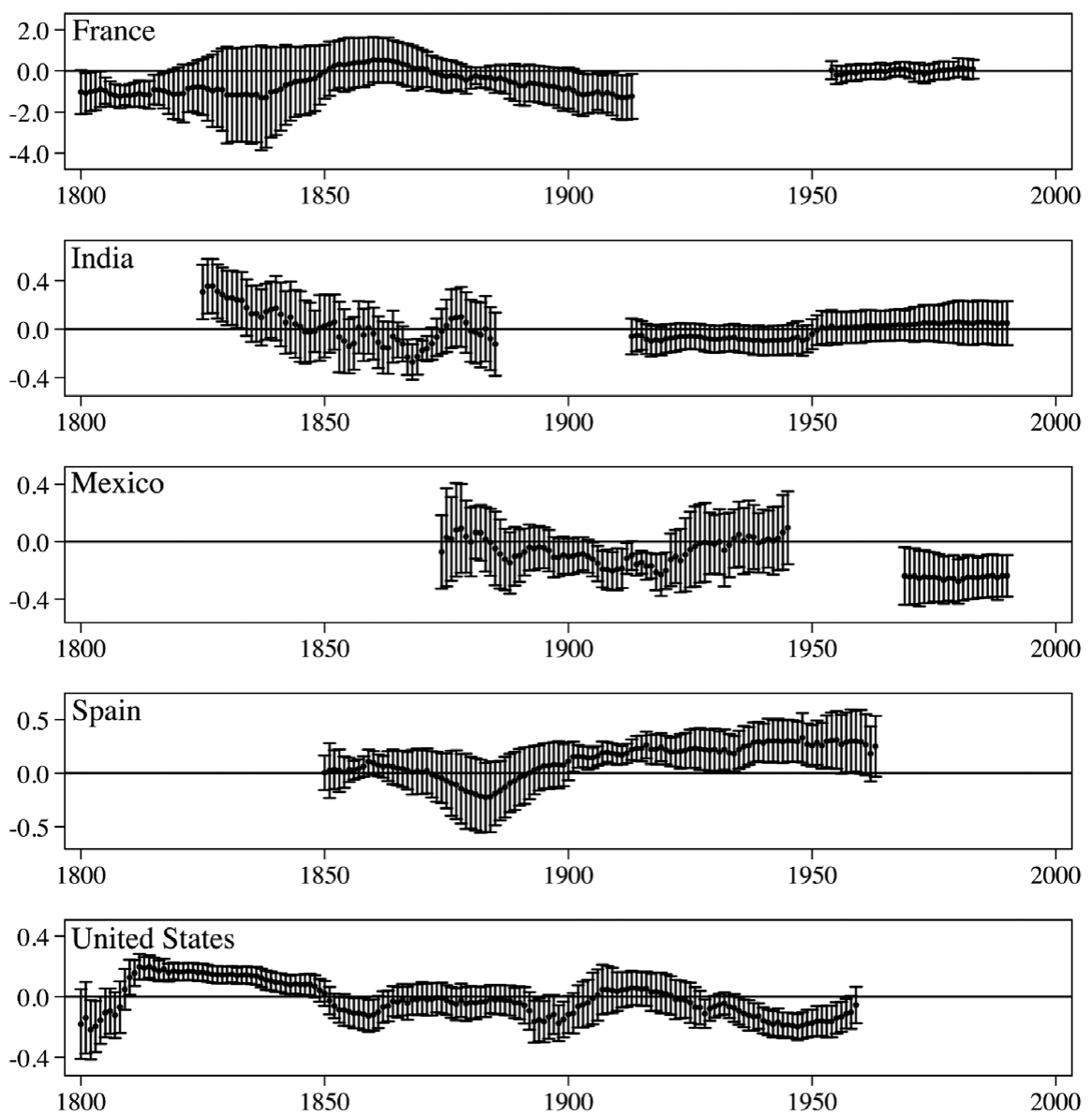

FIGURE 4. Results from rolling regressions of impact of temperature on stature. Sources: For height data see table 2; temperatures from Berkeley Earth Surface Temperature data set (www.berkeleyearth.org [accessed April 11, 2017]).

Note: Standard errors in these regressions have been computed after considering the clustering in the data.

was only statistically significant for a couple of decades in the early twentieth century. A stronger negative association emerged after the 1960s.

How might these results be explained in the context of the theoretical framework discussed earlier (see figure 1)? For the early-nineteenth-century United States, Floud et al. (2011: 301) said that the combination of abundant farmland and favorable climates was a major cause of the foundation and development of the early American "free land" economy. It may have been easier to grow crops in warmer areas as heights appear to have been positively correlated with temperatures. Then we observe 
an attenuation of this relationship from the mid-nineteenth century until the 1930s, as the share of agriculture as a proportion of economic activity decreased while economic growth and technological advances occurred concurrently. "Compared to farming, manufacturing depended less on seasonality or climate changes and more on technology and the quality of machines, tools, and operating power" (ibid.: 320).

However, figure 4 also suggests that during the 1930s a negative relationship emerged which might be linked to the "dust bowl" phenomenon of a semi-arid climate with dust storms and warm temperatures that greatly damaged the ecology and agriculture of the central and southern United States. This phenomenon had an uneven impact across the United States, with a particularly damaging effect on a belt of states ranging from the Dakotas through Nebraska, Colorado, Oklahoma, parts of Texas, and New Mexico between 1930 and 1936 (Landon-Lane et al. 2011: 81-82).

In Spain, heights were generally greater in warmer areas. As Simpson (1995: 256) notes: "About four-fifths of Spain's agricultural land suffered from seasonal droughts and low crop yields at the turn of the twentieth century. By contrast, the relatively high labour productivity in parts of the Mediterranean owed much to a combination of a warm climate, irrigation systems, artificial fertilisers and abundant labour which permitted the production of high value crops." However, for a period in the $1880 \mathrm{~s}$ this association was reversed. The 1880 s witnessed an agricultural decline with the disruption of the previous agrarian expansion (Garrabou i Segura 1975). The effects were felt largely in warmer and irrigated areas: "In the 1880 s, the fall in demand in Europe, the effects of the pests in the agriculture, the climatic irregularities with droughts and floods, and the problems of adapting to the enlargement of the [global] market, were felt in most of the irrigated areas" (Martínez-Carrión 1988: 155). This may have caused a reversal of the association between temperature and mean height. In addition, warm temperature is an important determinant of malaria, and this may also have had an effect on stature (Martínez-Carrión 1994). The argument here is that the higher incidence of malaria was always acting to suppress the height of those who grew up in warmer areas. For most of the period since 1850 until the eradication of malaria in Spain in the early twentieth century, this effect was more than counteracted by the greater success of agriculture in these areas, but during the 1880s the agricultural crisis prevented this counterbalancing of the malaria effect; indeed, differentials in agricultural production may temporarily have reinforced it.

In Mexico, we find a negative association between temperatures and stature from the 1890 s to the 1920 s and after the 1950s. Beyond the temperate center, warm areas in the north and the south were less conducive to growing crops (Guerrero Compean 2013). For example, when Fogel (1989: 318) evaluated the warm areas of north Mexico he said that "the arid lands acquired from Mexico were unsuitable for cotton and of dubious value for other crops." Warm areas in the south were also more prone to dengue fever and malaria (Rodriguez-Abrego et al. 2010). However, the negative relationship disappeared temporarily after the Revolution and the Cristero War, a period that was followed by the development of the welfare system, expansion of trade, and 40 years of sustained economic growth. During this period the government imported grain from abroad, mainly from the United States, to mitigate the effects 
of crop failure (López-Alonso 2012: 189). Since the 1950s, the negative association between temperature and stature has reemerged (Agüero 2014), which may be associated with the rapid increase in temperatures and the increase in the frequency of the ENSO.

In India, we find that men who were born in colder areas during the second quarter of the nineteenth century were shorter than men born in warmer areas, but this relationship appears to have largely disappeared after 1850. During the first half of the twentieth century, there was a weak negative relationship between temperature and stature, possibly due to the vulnerability to high temperatures of yields in the crops that were then grown (Easterly 2007). However, across the twentieth century any negative pattern in warm areas was overturned by the Green Revolution, which raised productivity and living standards in rural areas (Roy 2005).

Finally, we find that in nineteenth-century France people living in warmer areas were shorter, except for the decades of 1850s and 1860s (see also Dupin 1827 and Heyberger 2014). Yields of cereal crops were substantially higher in the colder northern areas in the early nineteenth century and, although there was progress in the central areas of the country, these regional disparities continued into the second half of the century (Newell 1973). However, the height differential between colder and warmer areas was reversed during the second half of the nineteenth century, in that people who were born in colder areas grew up to be shorter than people born in warmer areas. Given the lack of fluctuations in temperatures seen in table 1, this reversal might be connected to technological changes in agriculture (Toutain 1961). Newell (1973) argued that although growth in productivity occurred in the cold north during the first half of the nineteenth century, improvements such as the introduction of mixed farming and crop rotation had a greater impact in the warm south during the second half of the century. These improvements helped to reverse the negative association between height and temperature of the 1850s and 1860s.

After 1950 no relationship is observed, suggesting that in recent periods the relationship between temperature and stature has become weaker as a result of the technological changes that Fogel and Costa (1997) described. As seen in the agricultural revolution that occurred in the nineteenth century along with the railroad, financial, and commercial expansion, the percentage of people living in cities of more than 10,000 inhabitants rose from 8.9 percent in 1800 to 18.1 percent in 1870 (Malanima 2010). Schultz (1951) hypothesised that the effect of the increases in urbanization and industrialization on agriculture may operate through increased market effectiveness and reduced dependence on domestic agriculture as a source of food. There is clear evidence of a dramatic increase in food imports in France from the early twentieth century (National Bureau of Economic Research 2017), while Floud et al. (2011) reported that in France real wages increased by 192 percent in the period from 1945 to 1993.

Figure 4 also suggests that the beta coefficients from the nineteenth-century French data regression equations are greater than the coefficients for the other countries studied. It is not entirely clear why this should be the case, although we can suggest a number of possibilities. First, there is a limit to the absolute impact that climate can 
have on stature because variations in stature are limited by human physiology. Given the bounded nature of the potential impact of climate on height, the magnitude of the coefficients in each country will be affected by the absolute variability of the climate in that country over space and time. The climate within France has a lower variance and a smaller range in both temperature and precipitation than that of Mexico, India, or the United States. It may therefore not be surprising that any differential in stature in France would be associated with small differences in mean climate, and that the coefficients linking stature to these climatic variables would be larger in France than in the other countries. Second, the association between differences in climate and crop yields is nonlinear, so it is possible that the same absolute amount of difference in mean temperature or average precipitation has different effects in different countries. Third, the association between climate and stature in France may have been compounded by the independent effects of other variables, in ways that were less true elsewhere.

We turn now to the results for the effect of precipitation on stature (figure 5). In France the impact is negative between the 1840 s and the 1870 s, and this is followed by a positive association between 1870 and 1910 and no association in the second half of the twentieth century. However only for a brief period in the 1850 s and at the beginning of the twentieth century is the association statistically significant. Both the size and the strength of the association between precipitation and stature in Spain vary over time, but after 1900 the association becomes mostly negative. In India the association turns negative during the nineteenth century and remains so throughout the twentieth century. In Mexico a weak negative association seems to exist between the 1900s and 1920s, and this becomes more pronounced in the second half of the twentieth century. In the case of the United States, the negative association during the nineteenth century ceases in the 1890 s.

In France, men who were born in wet areas during the middle of the nineteenth century were, on average, shorter than those born in dry areas, consistent with a negative relationship between persistent levels of rain and stature in ancien régime France (Komlos et al. 2003) due to the negative relationship between abundant rainfall and crop yields (Le Roy Ladurie 1971). The reversal of this relationship during the final quarter of the nineteenth century may be explained by a combination of lower precipitation levels and new tariffs. Bassino and Dormois (2010: 37) emphasize the importance of the imposition of new tariffs on agricultural imports in the 1880s and assert that rainfall was a very important factor in explaining the development of wheat production under the tariff. Given the reduction in rainfall between 1840 and 1900 (table 1) and restrictions in trade, they pointed out that agricultural depression was felt more acutely in dry areas, where "wheat cropping became uneconomical in marginal areas that had been cultivated during the comparatively wetter and colder period up to 1870" (ibid.: 25). Bassino and Dormois were writing mainly about the Mediterranean littoral whereas our data derive mainly from central and eastern areas. Nevertheless, tariffs on agricultural imports were imposed nationally and so affected agriculture in all areas of the country.

The association between rainfall and stature in Spain is weak and rarely statistically significant. Our sample is mostly taken from the Mediterranean Levant, an area where 

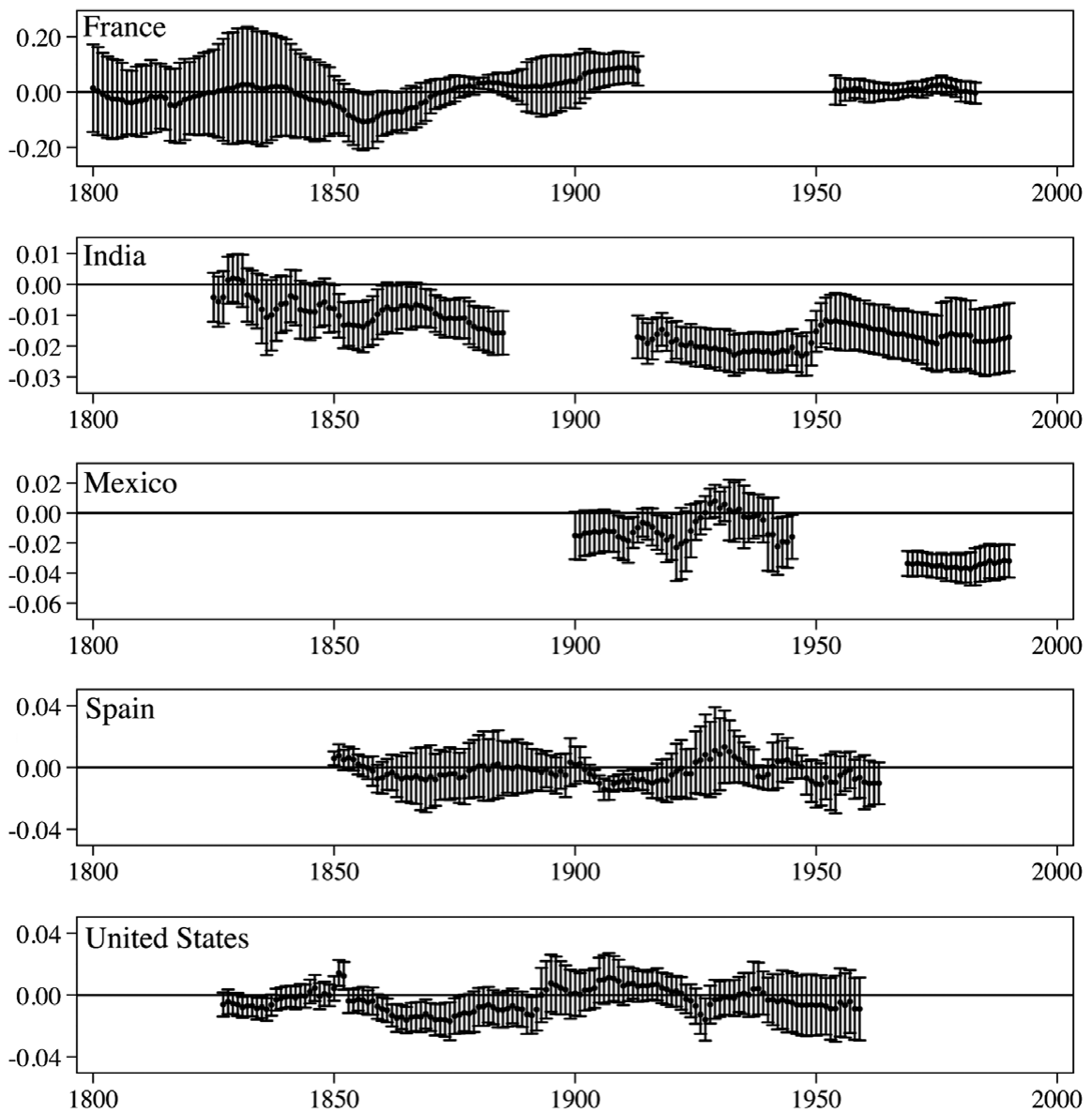

FIGURE 5. Results from rolling regressions of impact of precipitation on stature. Sources: For height data, see table 2; precipitation data from Harris et al. (2014), Casty et al. (2007), Carter et al. (2006), and Indian Institute of Tropical Meteorology. Notes: Standard errors in these regressions have been computed after considering the clustering in the data.

irrigation was widely practiced in agriculture. It may have been that irrigation weakened the relationship between rainfall and heights in areas that employed irrigation systems (Galofré-Vilà 2018b).

In the United States in the nineteenth century, people born in wetter areas were, on average, shorter than those living in dry areas. However, in the twentieth century no association is observed. According to Bleakley and Hong (2017: 773), "[h]ot and rainy short-term weather was less favourable for producing agricultural output 
in the late nineteenth century than it was in the late twentieth century and ... the adaptation of farm output value to weather occurred more-or-less steadily across decades." Thus, rapid change in the geographical pattern of crop production in agriculture, with technological adaptation in wet environments through drainage, fertilizer use, the selection of the crops, and hybrid seeds may have mitigated the negative effects of high precipitation on agricultural productivity (Floud et al. 2011; Hong 2011; Olmstead and Rhode 2008). Moreover, in the nineteenth century, wet areas were favorable to malaria transmission (Hong 2011) and malaria was prevalent in a vast area of the United States including the whole of the east, south, and Midwest apart from Appalachia and New England.

From the evidence available for Mexico during the twentieth century, it seems that the relationship between precipitation and stature resembles the relationship between temperature and stature: A weak negative association between the 1900s and 1920s that was stronger after the 1960s. This may be the result of the increasing levels of rain in Mexico after the 1940s as seen in table 1 (Guerrero Compean 2013). Heavy rains may have increased the burden from diseases felt in Mexico. For example, the proportion of children under five who had diarrhea in the two weeks preceding an interview conducted by the ENSANUT was higher in wet areas (Díaz Ortega et al. 2012). Heavy rainfall in wet areas may have led to hydrological erosion and the higher frequency of the ENSO may have contributed to negative effects on corn and the production of other crops (Conde et al. 1999).

The population of nineteenth-century India lived close to the margins of subsistence. In accounting for the Great Divergence, Parthasarathi (2011: 76) argued that in India "shortfalls in food production, whether due to climate or biology, were ... frequent, as were the famines that often accompanied harvest failures." Therefore, we might expect considerable sensitivity of heights to climatic fluctuations. It seems that the heights of people who are born in India have, since at least the mid-nineteenth century, been more sensitive to rainfall than temperature, and that people who are born in wetter areas have tended to be shorter than those born in dry areas. This has been found using modern nationally representative data: According to Deaton (2008), taller men are found in the states of Jammu and Kashmir $(168.3 \mathrm{~cm})$, Rajasthan $(167.5$ $\mathrm{cm})$, Punjab $(168.6 \mathrm{~cm})$, and Haryana $(168.1 \mathrm{~cm})$, being regions that receive annually less than $700 \mathrm{~mm}$ of rain. Men living in states that receive more than 2,000 $\mathrm{mm}$ of rain per year tend to be shorter $(166.2 \mathrm{~cm}$ in Goa, $163.6 \mathrm{~cm}$ in Assam, $161.6 \mathrm{~cm}$ in Tripura, $163.3 \mathrm{~cm}$ in Mizoram, and $157.2 \mathrm{~cm}$ in Meghalaya). Our results suggest that this pattern is long-standing.

This is not surprising due to the nature of the crops grown in dry and wet areas and of the structure of farming in the two areas (Roy 2016). Irrigated zones produced crops for export; people living in rain-fed areas often struggled to subsist (see also Tomlinson 1996). Disease was also more prevalent in wet areas, both in the form of malaria and gastrointestinal infections, and influenza (Donaldson and Keniston 2014). As Brennan et al. (1994: 204-5) observed: "Malaria and gastroenteric illnesses affected many among the population, including the children. It is not difficult to understand reduced final adult heights, given low childhood growth rates arising from illness and 
uneven food supply and compounded by problematic nutrition into the early adult years."

Taken together, these results suggest that the impact of climatic variations on stature has diminished over time and is now much more apparent in low- and middle-income countries than high-income countries. This supports the view that, over the course of the last two centuries, economic and technological changes have played a major role in changing the relationship between human beings and their environments in many parts of the world. However, we cannot exclude the possibility that changes in either temperature or precipitation may have affected people in different or even contradictory ways, leading us to underestimate the impact of these variables when the results are averaged across regions. We have tried to explore this by modeling the relationship in different ways, using quadratic or higher-order polynomials (see figure A3 in the appendix). The majority of the results are broadly consistent with those obtained from our initial analysis, but the results for France are more mixed. This may reinforce some of the concerns raised during our earlier discussion of the size of the coefficients in our French results and suggests that further research may be needed in this area.

\section{Conclusion}

The main aim of this article has been to describe changes in the relationship between temperature and precipitation, on the one hand, and average male stature, on the other, by looking at the impact of variations in the climate. We have shown how this relationship varied over time and between countries. In what are now wealthier or more "developed" countries, the relationship has become much weaker over time, but it remains important in poorer countries and in countries that have continued to be heavily dependent on domestic agriculture.

Fogel and Costa (1997) developed the concept of "technophysio evolution" to capture the extent to which human beings had gained increasing control over their environments since the early eighteenth century. The main elements of this process included breakthroughs in manufacturing, transportation, trade, communications, energy production, leisure-time services, and medical provision, alongside changes in agriculture (ibid.). However, much more work remains to be done to identify the particular combinations of changes that had the greatest impact on developments in individual countries.

In addition to considering the relationship between climate and stature in the past, it is also important to consider the possible implications of these changes for the future. Although average temperatures have increased in each of our countries over the course of the last two centuries, the pace of change in at least four of these countries-France, India, Mexico, and Spain — was quite slow up until the early years of the twentieth century, while temperatures have increased much more dramatically in France, Mexico, Spain, and the United States since the 1970s (see table 1). The process of "technophysio evolution" can be characterized as one of human emancipation from 
climatic constraints. However, the fact that human beings have gained increasing control over their environments during the last 200 years does not mean that we can take this for granted over the next two hundred years.

\section{Acknowledgments}

Earlier versions of this article were presented at the Annual Meeting of the Social Science History Association held in Vancouver, Canada, in November 2012; the meeting of the European Historical Economics Society held in London, United Kingdom, in September 2013; and the Economic History Society Annual Conference held in Warwick, United Kingdom, March 2014. We should like to thank participants in those meetings, Sabu Padmadas and Kris Inwood for their comments, the scholars who have shared their height data sets (see table 2), and Sok Chul Hong for his advice on methods. Gregori Galofré-Vilà's contribution to this research was funded by the United Kingdom Economic and Social Research Council, grant number ES/J500161/1.

\section{Supplementary material}

To view supplementary material for this article, please visit https://doi.org/10.1017/ ssh.2018.27

\section{References}

Agüero, J. (2014) "Long-term effect of climate change on health: Evidence from heat waves in Mexico." Inter-American Development Bank Working Paper 481.

Bassino, J-P., and Dormois, J. (2010) "Rainfall, the méline tariff, and wheat production in Mediterranean France, 1885-1914.” Australian Economic History Review 50 (1): 23-38.

Baten, J. (2001) "Climate, grain production and nutritional status in southern Germany during the XVIIIth century." Journal of European Economic History 30 (1): 9-47.

Bleakley, H., and S. C. Hong (2017) "Adapting to the weather: Lessons from US history." Journal of Economic History 77 (3): 756-95.

Bleakley, H., D. Costa, and A. Lleras-Muney (2013) "Health, education and income in the United States, 1820-2000." NBER Working Paper 19162.

Bodenhorn, H., T. Guinnane, and T. Mroz (2017) "Sample selection biases and the industrialization puzzle." Journal of Economic History 77 (1): 171-207.

Bogin, B. (1999) Patterns of Human Growth, 2nd ed. Cambridge: Cambridge University Press.

Brennan, L., J. MacDonald, and R. Shlomowitz (1994) "The height and economic well-being of North Indians under British rule." Social Science History 18 (2): 271-307.

Brennan, L., J. MacDonald, and R. Shlomowitz (1997) "Towards an anthropometric history of Indians under British rule." Research in Economic History 17: 185-246.

Carson, S. A. (2016) "Nineteenth-century white physical activity, calories and life expectancy: Nutrition, sanitation or medical intervention.” Journal of Interdisciplinary Economics 28 (2): 168-201.

Carter, S. B., S. S. Gartner, M. R. Haines, A. L. Olmstead, R. Sutch, and G. Wright (2006) Historical Statistics of the United States, Earliest Times to the Present: Millennial Edition. New York: Cambridge University Press.

Casty, C., C. R. Raible, T. F. Stocker, H. Wanner, and J. Luterbacher (2007) "European pattern climatology 1766-2000.” Climate Dynamics 29 (7-8): 791-805. 
Challú, A. (2009) "Agricultural crisis and biological well-being in Mexico." Historia Agraria 47: 21-44.

Checkley, W., G. Buckley, R. H. Gilman, A. M. Assis, R. L. Guerrant, S. S. Morris, K. Mølbak, P. ValentinerBranth, C. F. Lanata, R. E. Black, and the Childhood Malnutrition and Infection Network (2008) "Multicountry analysis of the effects of diarrhoea on childhood stunting." International Journal of Epidemiology 37 (2): 816-30.

Conde, C., R. M. Ferrer, C. Gay, V. Magaña, J. L. Pérez, T. Morales, and S. Orozco (1999) "El Niño y la agricultura," in: V. Magaña (ed.) Los Impactos de El Niño en México. Mexico: Universidad Nacional Autónoma de México: 103-35.

Costa, D. (2002) "The measure of man and older age mortality: Evidence from the Gould Sample." NBER Working Paper 8843.

Costa, D. (2015) "Health and the economy in the United States, from 1750 to the present." NBER Working Paper 19685.

Crafts, N. (1985) British Economic Growth during the Industrial Revolution. Oxford: Oxford University Press.

Cussó Segura, X., and R. Garrabou (2007) "La transición nutricional en la España contemporánea: Las variaciones en el consumo de pan, patatas y legumbres (1850-2000)." Investigaciones de Historia Económica 7: 69-100.

Deaton, A. (2008) "Height, health, and inequality: The distribution of adult heights in India." American Economic Review 92 (2): 468-74.

Dell, M., B. Jones, and B. Olken (2014) "What do we learn from the weather? The new climate-economy literature." Journal of Economic Literature 14 (3): 740-98.

Desai, S., R. Vanneman, and National Council of Applied Economic Research, New Delhi (2005) India Human Development Survey 2005. ICPSR22626-v11. Ann Arbor, MI: Inter-University Consortium for Political and Social Research.

Díaz Ortega, J. L., E. Ferreira, L. García, B. Trejo, M. M. Téllez Rojo, J. P. Gutiérrez, and M. Hernández Ávila. (2012) "Enfermedades diarreicas agudas en niños menores de cinco años: La respuesta es multifactorial.” Mexico: Encuesta Nacional de Salud y Nutrición, http://ensanut.insp.mx/doctos/analiticos/ EDA_EnfDiarAgu.pdf (accessed April 11, 2017).

Donaldson, D., and D. Keniston (2014) "How positive was the positive check? Investment and fertility in the aftermath of the 1918 influenza in India." Unpublished manuscript, www.econ.yale.edu/ egcenter/ Dave\%20 Donaldson.pdf (accessed April 11, 2017).

Dupin, C. (1827) Forces Productives et Commerciales de la France. Paris: Bachelier.

Easterly, W. (2007) "Inequality does cause underdevelopment: Insights from a new instrument." Journal of Development Economics 84 (2): 755-76.

Encuesta Nacional de Salud y Nutrición (2012) Encuesta Nacional de Salud y Nutrición 2012: Resultados Nacionales. México: Instituto Nacional de Salud Pública.

Eurobarometer (1996) Health Care Issues and Public Security (44.3). Brussels: INRA.

Eurobarometer (2003) Lifelong Learning, Health, and Partners and Fertility (59.0). Brussels: INRA.

Eurobarometer (2010) Foreign Languages, Biotechnology, Organized Crime, and Health Items (64.3). Brussels: INRA.

Floud, R., R. W. Fogel, B. Harris, and S. C. Hong (2011) The Changing Body: Health, Nutrition and Human Development in the Western World since 1700. Cambridge: Cambridge University Press.

Fogel, R. W. (1986) "Nutrition and the decline in mortality since 1700: Some preliminary findings," in S. Engerman and R. Gallman (eds.) Long-Term Factors in American Economic Growth. Chicago: University of Chicago Press: 439-555.

Fogel, R. W. (1989) Without Consent or Contract: The Rise and Fall of American Slavery, Vol. 1. New York: W. W. Norton.

Fogel, R. W. (1993) "New sources and new techniques for the study of secular trends in nutritional status, health, mortality, and the process of aging." Historical Methods 28 (1): 5-43.

Fogel, R. W., and D. Costa (1997) "A theory of technophysio evolution, with some implications for forecasting population, health care costs, and pension costs.” Demography 34 (1): 49-66. 
Fogel, R. W., S. L. Engerman, C. Pope, and L. Wimmer (1990) Union Army recruits in white regiments in the United States, 1861-1865. ICPSR09425. Ann Arbor, MI: Inter-University Consortium for Political and Social Research.

Fogel, R. W., S. Engerman, R. Floud, G. Friedman, R. A. Margo, K. Sokoloff, R. H. Steckel, T. J. Trussell, G. Villaflor, and K. Wachter (1983) "Secular changes in American and British stature and nutrition." Journal of Interdisciplinary History 14 (2): 445-81.

Food and Agriculture Organisation (1995) "Land and environmental degradation and desertification in Africa: Issues and options for sustainable economic development with transformation." Monograph European Commission on Agriculture/FAO Agriculture Division 10.

Galofré-Vilà, G., A. Guntupalli, and A. Hinde (2018a) "Heights across the last 2,000 years in England." Research in Economic History 34: 67-98

Galofré-Vilà, G., J. M. Martínez-Carrión, and J. Puche (2018b) "Height and climate in Mediterranean Spain, 1850-1949.” Journal of Interdisciplinary History 49 (2): 247-77.

Garrabou i Segura, R. (1975) "La crisi agrària espanyola de finals del segle XIX: Una etapa del desenvolupament del capitalisme." Recerques 5: 165-215.

Grajales-Porras, A., and M. López-Alonso (2011) "Physical stature of men in eighteenth-century Mexico: Evidence from Puebla.” Economics and Human Biology 9 (3): 265-71.

Guerrero Compean, R. (2013) "Weather and welfare: Health and agricultural impacts of climate extremes, evidence from Mexico." Inter-American Development Bank Working Paper 391. Washington, DC: Inter-American Development Bank.

Guntupalli, A. M., and J. Baten (2006) "The development and inequality of heights in North, West and East India 1915-1944.” Explorations in Economic History 43 (4): 578-608.

Harris, B., R. Floud, and S. C. Hong (2015) "How many calories? Food availability in England and Wales in the 18th century." Research in Economic History 31: 111-91.

Harris, I., P. D. Jones, T. J. Osborn, and D. H. Lister (2014) "Updated high-resolution grids of monthly climatic observations: The CRU TS 3.10 dataset.” International Journal of Climatology 34 (3): 623-42.

Heyberger, L. (2007) "Towards an anthropometric history of provincial France, 1780-1920." Economics and Human Biology 5 (2): 229-54.

Heyberger, L. (2014) "Received wisdom versus reality: Height, nutrition and urbanization in midnineteenth century France.” Cliometrica 8 (1): 115-40.

Holick, M. F. (2004) "Sunlight and vitamin D for bone health and prevention of autoimmune diseases, cancers and cardiovascular disease." American Journal of Clinical Nutrition 80 (6S): 1678S-88S.

Hong, S. C. (2011) "Malaria and economic productivity: A longitudinal analysis of the American case." Journal of Economic History 71 (3): 654-71.

Ingram, M. J., G. Farmer, and T. M. L. Wigley (1981) "Past climates and their impact on man," in T. M. L. Wigley, M. J. Ingram, and G. Farmer (eds.) Climate and History: Studies in Past Climates and Their Impact on Man. Cambridge: Cambridge University Press: 3-49.

Intergovernmental Panel on Climate Change (2001) The Scientific Basis: Contribution of Working Group I to the Third Assessment Report of the Intergovernmental Panel on Climate Change. Cambridge: Cambridge University Press.

International Social Survey Programme (2013) International Social Survey Programme Research Group: Health and Health Care. GESIS Data Archive, Data File Version 2.0.0.

Kelly, M., and C. Ó Gráda (2013) "Numerare est errare: Agricultural output and food supply in England during the industrial revolution." Journal of Economic History 73 (4): 1132-63.

Komlos, J., M. Hau, and N. Bourguinat (2003) "An anthropometric history of early modern France." European Review of Economic History 7 (2): 159-89.

Landon-Lane, J., H. Rockoff, and R. H. Steckel (2011) "Droughts, floods and financial distress in the United States," in G. Libecap and R. H. Steckel (eds.) The Economics of Climate Change: Adaptations Past and Present. Chicago: Chicago University Press: 37-98.

Le Roy Ladurie, E. (1971) Times of Feast, Times of Famine: A History of Climate since the Year 1000. London: George Allen and Unwin. 
Lloyd, S. J., R. S. Kovats, and B. G. Armstrong (2007) "Global diarrhoea morbidity, weather and climate." Climate Research 34 (2): 119-27.

López-Alonso, M. (2003) Height of Mexican Men and Women from Military Passport Records, 1870-1950. ICPSR03481-v1. Ann Arbor, MI: Inter-University Consortium for Political and Social Research.

López-Alonso, M. (2012) Measuring Up: A History of Living Standards in Mexico, 1850-1950. Redwood City, CA: Stanford University Press.

Malanima, P. (2010) "Urbanization," in: S. Broadberry and K. H. O'Rourke (eds.) The Cambridge Economic History of Modern Europe, Vol. 1: 1700-1870. Cambridge: Cambridge University Press: 235-63.

Martínez-Carrión, J. M. (1988) "Cambio agrícola y desarrollo capitalista: El sector agrario murciano a finales del siglo XIX, 1875-1914," in: R. Garrabou i Segura (ed.) La Crisis Agraria de Finales del Siglo XIX. Barcelona: Crítica: 131-60.

Martínez-Carrión, J. M. (1994) "Stature, welfare and economic growth in nineteenth-century Spain: The case of Murcia," in J. Komlos (ed.) Stature, Living Standards and Economic Development: Essays in Anthropometric History. Chicago: University of Chicago Press: 76-89.

Martínez-Carrión, J. M. (2002) "Biología, historia y medio ambiente. La estatura como espejo del nivel de vida de la sociedad Española." Ayer 46: 93-122.

Martínez-Carrión, J. M., and J. Moreno-Lázaro (2007) "Was there an urban height penalty in Spain 18401913?," Economics and Human Biology 5 (1): 144-64.

Meredith, D., and D. Oxley (2014) "Food and fodder: Feeding England 1700-1900." Past and Present 222: 163-214.

National Health and Nutrition Examination Survey (NHANES I) (1971-75) US Department of Health and Human Services. National Center for Health Statistics, 1971-75. Centers for Disease Control and Prevention.

National Health and Nutrition Examination Survey (NHANES II) (1976-80) US Department of Health and Human Services. National Center for Health Statistics, 1976-80. Centers for Disease Control and Prevention.

National Bureau of Economic Research (2017) "Macrohistory: VII. Foreign trade." www.nber.org/ databases/ macrohistory/contents/chapter07.html (accessed March 15, 2017).

Newell, W. (1973) “The agricultural revolution in nineteenth-century France.” Journal of Economic History 33 (4): 697-731.

Olaiz-Fernández, G., J. Rivera-Dommarco, T. Shamah-Levy, R. Rojas, S. Villalpando-Hernández, M. Hernández-Avila, and J. Sepúlveda-Amor (2006) Encuesta Nacional de Salud y Nutrición (2006), Cuernavaca, México: Instituto Nacional de Salud Pública.

Olmstead, A. L., and P. W. Rhode (2008) Creating Abundance: Biological Innovation and American Agricultural Development. Cambridge: Cambridge University Press.

Parthasarathi, P. (2011) Why Europe Grew Rich and Asia Did Not: Global Economic Divergence 16001850. Cambridge: Cambridge University Press.

Prados de la Escosura, L. (2007) "Inequality and poverty in Latin America: A long-run exploration," in T. Hatton, K. O'Rourke, and A. Taylor (eds.) The New Comparative Economic History: Essays in Honor of Jeffrey G. Williamson. Boston: Massachusetts Institute of Technology Press: 291-316.

Puche, J. (2011) "Evolución del nivel de vida biológico en la Comunidad Valenciana, 1840-1969." Investigaciones de Historia Económica 7 (3): 380-94.

Pullum, T. (2006) "An assessment of age and date reporting in the DHS Surveys, 1985-2003." Demographic and Health Surveys Methodological Reports No. 5. Macro International.

Rodriguez-Abrego, G., J. Escobedo, and R. Zurita Garza (2010) "Burden of disease between two time frames: Mexico perspectives," in V. Preedy and R. Watson (eds.) Handbook of Disease Burdens and Quality of Life Measures. New York: Springer: 484-501.

Roy, T. (2005) Rethinking Economic Change in India: Labor and Livelihood. London: Routledge.

Roy, T. (2016) "The British Empire and the economic development of India 1858-1947." Journal of Iberian and Latin American Economic History 34 (2): 209-36. 
Schultz, T. W. (1951) "A framework for land economics. The long view." Journal of Farm Economics 33 (2): 204-15.

Scrimshaw, N. S., and J. P. SanGiovanni (1997) "Synergism of nutrition, infection and immunity: An overview." American Society for Clinical Nutrition 66 (2): 464S-74S.

Sharpe, P. (2012) "Explaining the short stature of the poor: Chronic childhood disease and growth in nineteenth-century England." Economic History Review 65 (4): 1475-94.

Simpson, J. (1995) Spanish Agriculture: The Long Siesta, 1765-1965. Cambridge: Cambridge University Press.

Small, J., S. J. Goetz, and S. I. Hay (2003) "Climatic suitability for malaria transmission in Africa, 19111995." Proceedings of the National Academy of Sciences 100 (26): 15341-45.

Steckel, R. H. (1992) Confederate Amnesty Records for the United States Civil War, 1863-1866. ICPSR09429. Ann Arbor, MI: Inter-University Consortium for Political and Social Research.

Steckel, R. H., and J. C. Rose (2002) The Backbone of History: Health and Nutrition in the Western Hemisphere. Cambridge: Cambridge University Press.

Sunder, M. (2013) "The height gap in 19th-century America: NMet-nutritional advantage of the elite increased at the onset of modern economic growth." Economics and Human Biology 11 (3): 245-58.

Tanner, E. (1962) Growth at Adolescence: With a General Consideration of the Effects of Hereditary and Environmental Factors upon Growth and Maturation from Birth to Maturity. Oxford: Blackwell.

Tomlinson, B. (1996) The New Cambridge History of India. Vol. 3: The Economy of Modern India, 1860-1970, 2nd ed. Cambridge: Cambridge University Press.

Toutain, J. (1961) "Le produit de l'agriculture française de 1700 a 1958-La croissance," in Cahiers de l'Institute de Science Economique Appliquée. Paris: Institute de Science Economique Appliquée.

Vörösmarty, C., J. P. Green, J. Salisbury, and R. B. Lammers (2000) "Global water resources: Vulnerability from climate change and population growth." Science 289 (5477): 284-8.

Wachter, K., and Trussell, J. (1982) "Estimating historical heights: Rejoinder." Journal of the American Statistical Association 77 (378): 301-3.

World War II Army Enlistment Records (2005) World War II Army Enlistment Records. National Archives and Records Administration Record Group 64. US National Archives.

Wu, J. (1994) "How severe was the Great Depression? Evidence from the Pittsburgh region," in J. Komlos (ed.) Stature, Living Standards, and Economic Development: Essays in Anthropometric History. Chicago: University of Chicago Press: 129-52.

Zehetmayer, M. (2011) "The continuation of the antebellum puzzle: Stature in the US 1847-1894." European Review of Economic History 15 (2): 313-27. 